УДК 553.2: 549.283 (571.52)

\title{
ЗОЛОТО-СУЛЬФИДНО-КВАРЦЕВОЕ РУДОПРОЯВЛЕНИЕ АРЫСКАН (ЗАПАДНАЯ ТУВА): УСЛОВИЯ ОБРАЗОВАНИЯ И ГЕОХИМИЧЕСКИЕ ОСОБЕННОСТИ ФЛЮИДОВ
}

\author{
Кужугет Ренат Васильевич1, \\ rkuzhuget@mail.ru
}

\section{Анкушева Наталья Николаевна2,3, ankusheva@mail.ru}

Редина Анна Андреевна4,
anna-red@outlook.com

\section{Прокопьев Илья Романович4,5,} prokopev_ilya@mail.ru

\section{Ондар Эртине-Даш Васильевич 6 ,} ondar21@mail.ru

\author{
1 Тувинский институт комплексного освоения природных ресурсов СО РАН, \\ Россия, 667007, г. Кызыл, ул. Интернациональная, 117 а. \\ 2 Институт минералогии ЮУ ФНЦ МиГ УрО РАН, \\ Россия, 456317, Челябинская обл., г. Миасс, Ильменский заповедник, 1. \\ 3 Южно-Уральский государственный университет, филиал в г. Миассе, \\ Россия, 456316, г. Миасс, ул. 8 июля, 10. \\ 4 Институт геологии и минералогии СО РАН, \\ Россия, 630090, г. Новосибирск, пр. Ак. Коптюга, 3. \\ 5 Новосибирский государственный университет, \\ Россия, 630090, г. Новосибирск, ул. Пирогова, 1 \\ 6 Тувинский государственный университет, \\ Россия, 667000, г. Кызыл, ул. Ленина, 36.
}

Актуальность исследования обусловлена необходимостью определения генезиса и условий образования золоторудных объектов Тувы для повышения эфффективности геолого-поисковых работ по наращиванию минерально-сырьевой базы золота региона.

Цель: определение условий образования и геохимических особенностей рудообразующих фрлюидов рудопроявления золота Арыскан в Западной Туве.

Mетоды. Флюидные включения проанализированы с помощью термокамеры Linkam TMS-600 с микроскоnом Olympus BX 51 c иелью определения температур, солевого состава, концентрации солей и давления фрлюида при минералообразовании; газовый состав индивидуальных фрлюидных включений определен на рамановском спектрометре Ramanor U-1000 с детектором Horiba DU420E-OE-323, лазер Millennia Pro (Spectra-Physics); валовый газовый состав фрлюида определен на газовом хроматографре Agilent 6890, содержания анионов в водной вытяжке оценены на ионном хроматографре ЦВЕТ-3000, содержания катионов и микроэлементов - методом ICP MS (Elan-6100); соотношения изотопов серы определены на газовом массспектрометре Finnigan MAT Delta.

Результаты. В результате проведенных исследований установлено, что березиты рудопроявления сфоормировались при участии углекислото-водно-солевых фрлюидов с соленостью 4,9-41,5 мас. \% экв. NaCl при температурах не менее $250-340^{\circ} \mathrm{C}$. Золотосодержащие минеральные ассоциации образовались при $\mathrm{P} \sim 1,8$ кбар ( 5,4 км) из фрлюидов состава $\mathrm{NaCl}-\mathrm{KCl}-\mathrm{H}_{2} \mathrm{O}$, $\mathrm{NaCl}-\mathrm{Na}_{2} \mathrm{HCO}_{4}-\mathrm{H}_{2} \mathrm{O}$ и NaCl- $\mathrm{H}_{2} \mathrm{O}$, содержащих $\mathrm{CO}_{2}$, с кониентрациями 2,9-32,9 мас. \% NaCl-экв., на фоне снижения температур в интервале $290-145{ }^{\circ} \mathrm{C}$ (золото-сульфидно-квариевые жилы - 290-145 ${ }^{\circ} \mathrm{C}$, золото-теллуридно-сульфридно-кварцевые жилы $\left.270-160{ }^{\circ} \mathrm{C}\right)$, при вариациях $\mathrm{fO}_{2}, f \mathrm{~S}_{2}$, $f \mathrm{Se}_{2}$ uf $\mathrm{Te}$. Изотопный $\delta^{34} \mathrm{~S}_{2} \mathrm{~S}$ (om $-0,5$ до +1,1\%), солевой и микроэлементный состав минералообразующих фрлюидов свидетельствуют о его магматическом происхождении.

\section{Ключевые слова:}

Золото, березиты, месторождения золота, квари, Тува, фрлюидные включения, микроэлементы, изотопия серы.

\section{Введение}

Республика Тыва является в своем роде уникальной металлогенической провинцией, где выявлены месторождения цветных, редких и благородных металлов. Ресурсный потенциал региона по Аu оценивается в 400 т, из которых 20 т сосредоточено в россыпных месторождениях. Однако золоторудные объекты региона недостаточно изучены (разведаны) в плане геолого-промышленных параметров, минералого-геохимических особенностей и условий образований руд. 
Одним из перспективных на коренное $\mathrm{Au}$ в регионе является Алдан-Маадырский рудный узел (АМРУ), к которому относятся небольшие рудопроявления $\mathrm{Au}$, открытые в 1950-70-х гг. при геолого-съемочных и поисковых работах. Эти объекты залегают в осадочных породах (Улуг-Саир, Ак-Даг), березитах (Арыскан, Дуушкуннуг, Ак-Даш) и лиственитах (ХаакСаир).

AMPУ располагается в области развития $\mathrm{V}-\mathrm{C}_{1}$ океанических комплексов и $\mathrm{S}-\mathrm{O}$ пород коллизионного прогиба. Золотое оруденение парагенетически связано с интрузивными породами баянкольского комплекса $\left(\mathrm{D}_{3}\right)$ и сопряжено с процессами березитизации и лиственитизации рудовмещающих пород $[1,2]$, а также контро- лируется оперяющими разломами субширотного простирания Хемчикско-Куртушибинского (СаяноТувинского) глубинного разлома, которые осложняют линейные антиклинали и горстантиклинали той же ориентировки.

\section{Геолого-минералогическая характеристика} рудопроявления Арыскан

Рассматриваемое рудопроявление приурочено к антиклинальной структуре длиной 6 км, шириной 2-3 км. Структура осложнена субширотными разломами, которые смещаются на 120-150 м разломом СВ простирания (рис. 1). Геолого-минералогическая характеристика рудопроявления Арыскан приведена в работе [2].

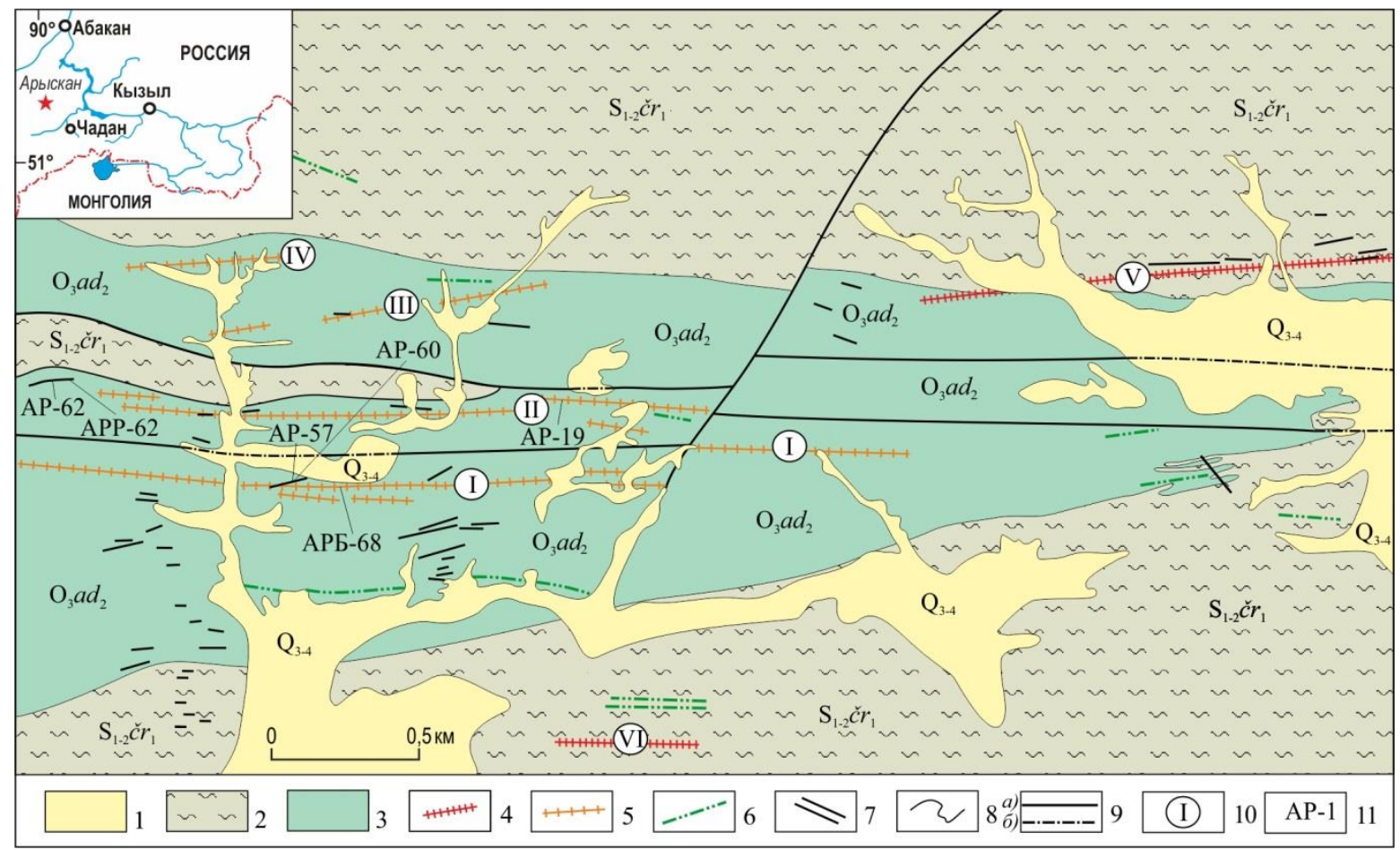

Pис. 1. Схема геологического строения Арысканского рудопроявления (по данным [3, 4] с изменениями авторов): 1 делювиально-пролювиальные отложения $\left(Q_{3-4}\right) ; 2$ - серицито-глинистые сланцы и алевролиты чергакской свиты $\left(S_{1-2} \check{c} r_{1}\right) ; 3$ - алевролиты и песчаники адырташской свиты $\left(O_{3} a d_{2}\right) ; 4$ - дайки березитизированных риолитов и гранодиоритов II фазы баянкольского комплекса $\left(D_{3} b n\right)$; 5 - березиты по осадочным породам; 6 дайки диорит-порфиров III фазы баянкольского комплекса $\left(D_{3} b n\right) ; 7$ - жильные зоны и квариевые жиль;; 8 геологические гранииы; 9 - достоверные (а) и предполагаемые (б) разрывные нарушения; 10- номера зон березитов; 11 -места отбора и номера проб

Fig. 1. Scheme of geological structure of Aryskan ore occurrence (according to [3, 4], modified): 1-deluvial-proluvial sediments $\left(Q_{3-4}\right) ; 2$ - sericite-clayey schists and aleurolites of Chergak Suit $\left(S_{1-2} \check{c} r_{1}\right) ; 3$-aleurolites and sandstones of Adyrdash Suit $\left(\mathrm{O}_{3} a d_{2}\right) ; 4$ - beresitized rhyolite and granodiorite dykes of II phase of Bayancol complex $\left(D_{3} b n\right) ; 5$ beresitized sedimentary rocks; 6 - diorite dykes of III phase of Bayancol complex $\left(D_{3} b n\right) ; 7$ - quartz veins and zones; 8 -geological boundaries; 9 -faults reliable (a) and supposed (6); 10-beresitized zones; 11 -samples

Магматические породы представлены дайками риолит-порфиров, гранодиорит-порфиров II фазы и микродиоритами III фазы баянкольского комплекса $\left(\mathrm{D}_{3} b n\right)$ в ордовикских и силурийских отложениях.

Золото локализовано в сульфидно-кварцевых жилах (сульфиды менее 3 \%) и прожилках штокверкового типа в осадочных породах и березитах. В процессе геолого-съёмочных и поисковых работ выявлено 6 зон березитов субширотного простирания: зоны I-IV развиваются за счет алевролитов и кварцевых песчаников; зоны V-VI - по дайкам риолитовпорфиров и гранодиоритов-порфиров (рис. 1).

Протяженность березитов по осадочным породам прослеживается на 0,2-4 км (в среднем 1500-1800 м), мощность - 0,2-5 м (в среднем 1-3 м). Форма тел «занозистая», залегание крутое $\left(75-90^{\circ}\right)$. Березиты представляют собой кварц-карбонатные породы с вкрапленностью пирита (до 1 \%) и чешуйками серицита (до $15 \%$ ), пронизанные тонкими пириткварцевыми прожилками (рис. 2). 

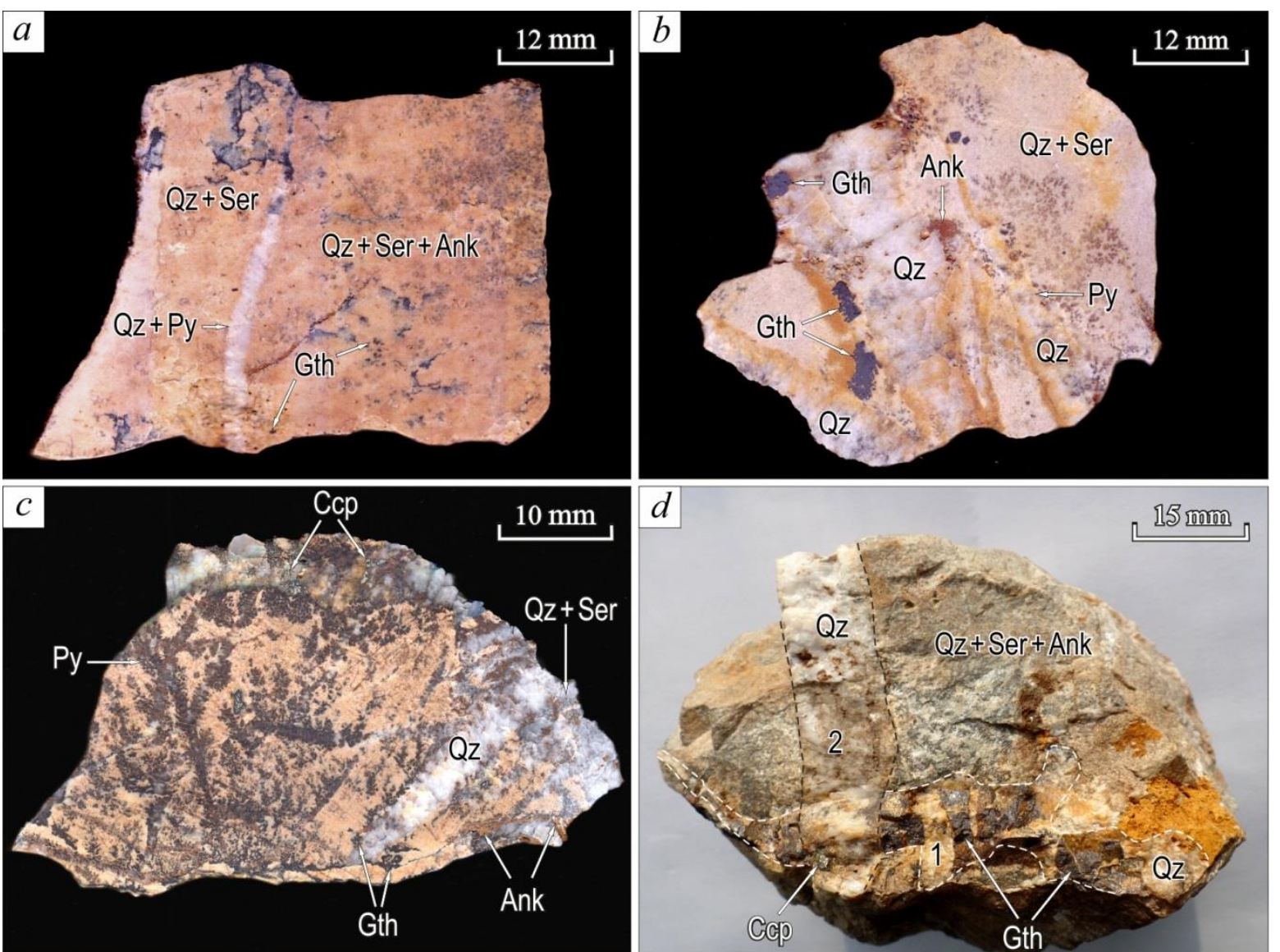

Pис. 2. Типы березитов: а) березит по гранодиорит-порфиру; $b$, c) березиты по песчанику с пирит-квариевыми и халькопирит-квариевыми прожилками; d) золото-сульфидно-квариевая жила рассечена золото-теллуридно-

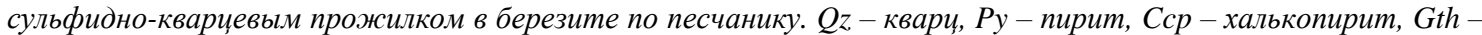
лимонит по пириту, Ank - анкерит, Ser-серицит

Fig. 2. Types of berezites: a) porphyry granodiorite beresite; $b, c)$ sandstone beresites with pyrite-quartz and chalcopyritequartz veins; d) Au-sulfide-quartz vein is fractured by Au-telluride-quartz vein in sandstone beresite. Qz-quartz, Py-pyrite, Ccp-chalcopyrite, Gth-limonite, Ank-ankerite u Ser-sericite

Простирание даек березитизированных риолитов и гранодиоритов субширотное, падение вертикальное, их контакты с вмещающими породами секущие. По данным [3-5], протяженность березитов прослеживается от 0,5 до 2 км, мощность колеблется от 0,2 до 1,5 м. Березиты сложены альбитом (до $60 \%$ ), серицитом (до $15 \%$ ), кварцем (20-25\%), карбонатом (кальцитом и анкеритом) (до $10 \%$ и и пиритом в виде хорошо огранённых кубических кристаллов (до 5 \%).

Минерализация золота в кварцевых жилах и метасоматитах носит прожилковый, прожилкововкрапленный и рассеянно-вкрапленный характер. По данным [3, 5], содержание Au в зонах I-IV колеблется от следов до 31,6 г/т, составляя, в среднем, от 1,4 г/т, в зонах V-VI - от следов до 0,6 до 1 г/т.

По данным предшественников [4] и собственным наблюдениям [2], на рудопроявлении выделяются следующие стадии: березитовая (1) и пирит-кварцевая (2); золото-сульфидно-кварцевая (3) и золото-теллуридносульфидно-кварцевая (4) и карбонатно-кварцевая (5) и хлорит-гематит-кварцевая (6) (рис. 2, г, 3).

Ранняя минерализация проявлена в образовании березитов и сопряженных с ними безрудных пириткварцевых жил (длиной до 4,5 м, мощностью 0,7 м) с шеелитом, которые рассекают вмещающие осадочные породы и березиты.

Золото-сульфидно-кварцевые жилы наложены на минеральные агрегаты березитов. Они сложены белым и молочно-серым сливным мелкозернистым кварцем, имеют близкое к вертикальному залегание, мощность от десятков сантиметров до 1 м и протяженность от 15 до 50 м. В свою очередь, эти жилы отчетливо рассечены более поздними молочнобелыми золото-теллуридно-сульфидно-кварцевыми жилами.

Золото в золото-сульфидно-кварцевых жилах образует мелкие включения (до 1 мм) в кварце, халькопирите и галените (рис. 4) и по химическому составу имеет следующий состав (мас. \%): $\mathrm{Au} 80,72-93,75, \mathrm{Ag}$ 6,33-18,89, Cu 0,01-0,40, Hg 0,00-0,24, Te 0,00-0,05. По морфологии преобладают трещинно-прожилковые, комковидно-ветвистые и ксеноморфные зерна.

Поздние золото-теллуридно-сульфидно-кварцевые жилы рассекают ранние золото-сульфидно-кварцевые жилы в березитизированных песчаниках и алевролитах. Золото в них ассоциирует с сульфидами, блеклыми рудами (Zn-теннантит-тетраэдрит), теллуридами (петцит, гессит, теллуровисмутит, цумоит, алтаит, 
самородный теллур) и селенидами (фишессерит, клаусталит) (рис. 5), представлено зернами различной морфологии размером до 100 мкм. Золото имеет следующий состав (мас. \%): Au 86,01-91,56, Ag 7,47$13,779, \mathrm{Cu} 0,00-0,25$ мас. \%. В золоте и кварце отмечаются включения (до 5 мкм) Se-содержащего алтаита, теллуровисмутита (до 12 мкм) и букхорнита (5-10 мкм) (табл. 1). Выявленные теллуриды и селениды образуют мелкие (5-20 мкм) включения в кварце, халькопирите и гетите. Химический состав букхорнита показан в табл. 2 .

По составу рудных минералов рудопроявление Арыскан отвечает золото-пирит-халькопиритовому типу с теллуридами (петцит, гессит, теллуровисмутит, цумоит, алтаит), селенидами (фишессерит, клаусталит) и букхорнитом (сульфотеллурид $\mathrm{Au}$ и $\mathrm{Pb}$ ).

\begin{tabular}{|c|c|c|c|c|c|c|c|}
\hline \multirow{4}{*}{$\begin{array}{c}\text { Минералы } \\
\text { Minerals }\end{array}$} & \multicolumn{7}{|c|}{ Этапы / Stages } \\
\hline & \multicolumn{6}{|c|}{$\begin{array}{c}\text { Гидротермальный золото-сульффидно-кварцевый } \\
\text { Hydrothermal gold-sulfide-quartz }\end{array}$} & \multirow{3}{*}{$\begin{array}{l}\text { Гипергенный } \\
\text { Supergene }\end{array}$} \\
\hline & \multicolumn{6}{|c|}{ Стадии / Substages } & \\
\hline & 1 & 2 & 3 & 4 & 5 & 6 & \\
\hline Кварц / Quartz & $\longrightarrow$ & $\longrightarrow$ & $\longrightarrow$ & $\longrightarrow$ & $\longrightarrow$ & $\longrightarrow$ & \\
\hline Серицит / Sericite & $\longrightarrow$ & & $=$ & & & & \\
\hline Альбит / Albite & $\longrightarrow$ & & & & & & \\
\hline Пирит / Pyrite & 2 & $\longrightarrow$ & 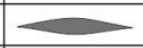 & $\longrightarrow$ & & & \\
\hline Сидерит / Siderite & $\longrightarrow$ & & & & & & \\
\hline Анкерит / Ankerite & $=$ & & & & & 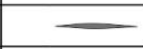 & \\
\hline Шеелит / Scheelite & & $\longrightarrow$ & & & & & \\
\hline Гематит / Hematite & & $\longrightarrow$ & & & & $\longrightarrow$ & \\
\hline Хлорит / Chlorite & & & - & & & $\longrightarrow$ & \\
\hline Халькопирит / Chalcopyrite & & & $\longrightarrow$ & $\longrightarrow$ & & & \\
\hline Галенит / Galena & & & $\longrightarrow$ & $\longrightarrow$ & & & \\
\hline Борнит / Bornite & & & & $=$ & & & \\
\hline Золото / Native gold & & & & $=$ & & & \\
\hline Петцит / Petzite & & & & $=$ & & & \\
\hline Гессит / Hessite & & & & - & & & \\
\hline Алтаит / Altaite & & & & $\longrightarrow$ & & & \\
\hline Se-алтаит / Se-altaite & & & & - & & & \\
\hline Букхорнит / Buckhornite & & & & $\longrightarrow$ & & & \\
\hline Теллуровисмутит / Tellurobismuthite & & & & - & & & \\
\hline Цумоит / Tsumoite & & & & - & & & \\
\hline Блёклые руды / Fahlores & & & & - & & & \\
\hline Сфралерит / Sphalerite & & & & $\longrightarrow$ & & & \\
\hline Клаусталит / Clausthalite & & & & $\longrightarrow$ & & & \\
\hline Фишессерит / Fischesserite & & & & - & & & \\
\hline Самородный теллур / Tellurium & & & & $=$ & & & \\
\hline Барит / Baryte & & & & - & & & \\
\hline Кальцит / Calcite & & & & & $\longrightarrow$ & & \\
\hline Fe-доломит / Fe-dolomite & & & & & & $\longrightarrow$ & \\
\hline Гипергенные / Supergene & & & & & & & $<$ \\
\hline Акантит / Acanthite & & & & & & & $\longrightarrow$ \\
\hline Ковеллин / Covellite & & & & & & & $\longrightarrow$ \\
\hline Халькозин / Chalcocite & & & & & & & $\longrightarrow$ \\
\hline Малахит / Malachite & & & & & & & $\longrightarrow$ \\
\hline Азурит / Azurite & & & & & & & $=$ \\
\hline Скородит / Scorodite & & & & & & & - \\
\hline Церуссит / Cerussite & & & & & & & - \\
\hline Глёт / Litharge & & & & & & & $=$ \\
\hline Гётит / Goethite & & & & & & & $\longrightarrow$ \\
\hline Чеховичит / Chekhovichite & & & & & & & - \\
\hline Ютенбогаардтит / Uytenbogaardtite & & & & & & & - \\
\hline Сepeбpo / Silver & & & & & & & - \\
\hline
\end{tabular}

Рис. 3. Последовательность минералообразования рудопроявления Арыскан

Fig. 3. Mineral formation sequence of Aryskan ore occurrence 

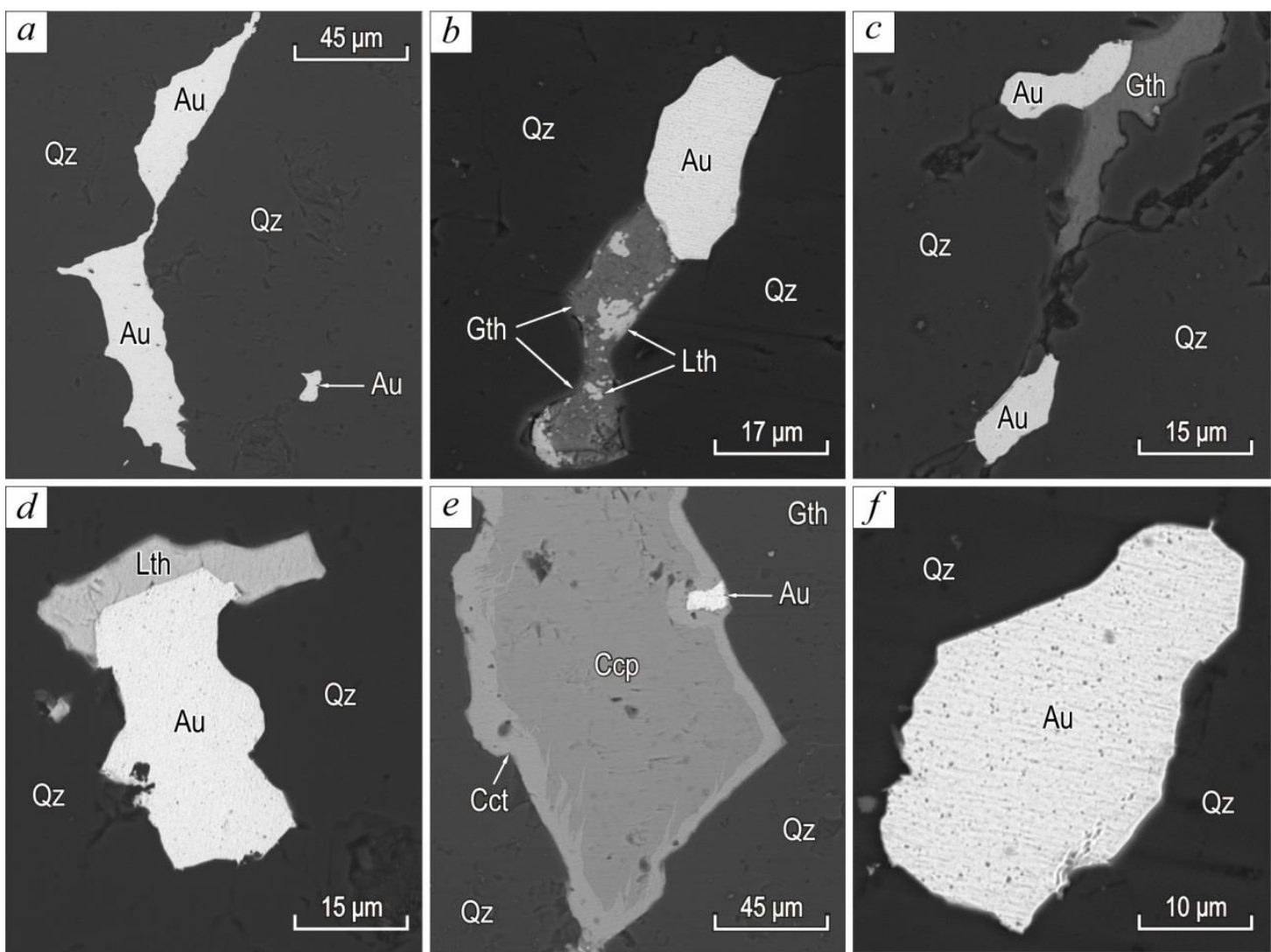

Pис. 4. Золото в золото-сульфидно-квариевых жилах с халькопиритом (Ccp), халькозином (Ссt), гётитом (Gth) u глётом (Lth). Изображение в обратно-рассеянных электронах

Fig. 4. Gold in Au-sulfide-quartz veins with chalcopyrite (Ccp), chalcocite (Cct), goethite (Gth) and litharge (Lth). BSE image

Таблица 1. Химический состав теллуридов и селенидов (мас. \%)

Table 1. Chemical composition of tellurides and selenides (wt. \%)

\begin{tabular}{|c|c|c|c|c|c|c|c|c|c|}
\hline $\begin{array}{c}\text { Анализ } \\
\text { Analysis }\end{array}$ & $\mathrm{Ag}$ & $\mathrm{Au}$ & $\mathrm{Pb}$ & $\mathrm{Bi}$ & $\mathrm{S}$ & $\mathrm{Te}$ & $\mathrm{Se}$ & $\begin{array}{c}\text { Сумма } \\
\text { Total }\end{array}$ & $\begin{array}{c}\text { Формула } \\
\text { Formula }\end{array}$ \\
\hline \multicolumn{10}{|c|}{ Петцит/Petzite } \\
\hline 1 & 40,99 & 25,59 & - & - & - & 32,54 & - & 99,12 & $\mathrm{Ag}_{2,98} \mathrm{Au}_{1,02} \mathrm{Te}_{2,00}$ \\
\hline 2 & 41,86 & 25,53 & - & - & - & 32,31 & - & 99,70 & $\mathrm{Ag}_{3,02} \mathrm{Au}_{1,01} \mathrm{Te}_{1,97}$ \\
\hline 3 & 41,38 & 25,72 & - & - & - & 32,76 & - & 99,86 & $\mathrm{Ag}_{2,99} \mathrm{Au}_{1,01} \mathrm{Te}_{2,00}$ \\
\hline 4 & 41,72 & 25,62 & $\begin{array}{l}- \\
\end{array}$ & - & - & 32,89 & - & 100,23 & $\mathrm{Ag}_{3,00} \mathrm{Au}_{1,01} \mathrm{Te}_{1,99}$ \\
\hline 5 & 41,21 & 25,26 & - & - & - & 32,69 & - & 99,16 & $\mathrm{Ag}_{2,99} \mathrm{Au}_{1,00} \mathrm{Te}_{2,01}$ \\
\hline \multicolumn{10}{|c|}{ Гессит/Hessite } \\
\hline 6 & 63,21 & - & - & - & - & 36,67 & - & 99,88 & $\mathrm{Ag}_{2,01} \mathrm{Te}_{0,99}$ \\
\hline 7 & 62,22 & - & - & - & - & 36,98 & - & 99,20 & $\mathrm{Ag}_{2,00} \mathrm{Te}_{1,00}$ \\
\hline \multicolumn{10}{|c|}{ Алтаит/Altaite } \\
\hline 8 & 1,93 & - & 58,34 & - & - & 39,14 & - & 99,41 & $\left(\mathrm{~Pb}_{0,93} \mathrm{Ag}_{0,06}\right)_{0,99} \mathrm{Te}_{1,01}$ \\
\hline 9 & - & - & 62,28 & - & - & 36,30 & 1,11 & 99,69 & $\mathrm{~Pb}_{1,00}\left(\mathrm{Te}_{0,95} \mathrm{Se}_{0,05}\right)_{1,00}$ \\
\hline \multicolumn{10}{|c|}{ Теллуровисмутит/Tellurobismuthite } \\
\hline 10 & - & - & - & 51,14 & - & 48,11 & - & 99,25 & $\mathrm{Bi}_{1,97} \mathrm{Te}_{3,03}$ \\
\hline 11 & - & - & - & 52,03 & - & 47,11 & - & 99,14 & $\mathrm{Bi}_{2,01} \mathrm{Te}_{2,99}$ \\
\hline 12 & - & - & - & 52,07 & - & 47,53 & - & 99,60 & $\mathrm{Bi}_{2,00} \mathrm{Te}_{3,00}$ \\
\hline \multicolumn{10}{|c|}{ Цумоит/Tsumoite } \\
\hline 13 & - & - & - & 61,53 & - & 38,32 & - & 99,85 & $\mathrm{Bi}_{0,99} \mathrm{Te}_{1,01}$ \\
\hline 14 & - & - & - & 63,17 & - & 36,13 & - & 99,30 & $\mathrm{Bi}_{1,03} \mathrm{Te}_{0,97}$ \\
\hline \multicolumn{10}{|c|}{ Клаусталит/Clausthalite } \\
\hline 15 & - & - & 73,81 & & 1,53 & & 23,78 & 99,12 & $\mathrm{~Pb}_{1,01}\left(\mathrm{Se}_{0,86} \mathrm{~S}_{0,13}\right)_{0,99}$ \\
\hline \multicolumn{10}{|c|}{ Фишессерит/Fischesserite } \\
\hline 16 & 50,14 & 30,28 & - & - & 3,34 & - & 15,83 & 99,59 & $\mathrm{Ag}_{3,02} \mathrm{Au}_{1,00}\left(\mathrm{Se}_{1,30} \mathrm{~S}_{0,68}\right)_{1,98}$ \\
\hline 17 & 47,56 & 28,94 & - & - & - & - & 22,92 & 99,42 & $\mathrm{Ag}_{3,01} \mathrm{Au}_{1,01} \mathrm{Se}_{1,98}$ \\
\hline
\end{tabular}

Примечание. Здесь и далее составы минералов определялись на SEM MIRA LM (ИГM CO РАН, г. Новосибирск). Формула гессита рассчитана на 3 ат., алтаита и клаусталита - на 2 ат., петиита и фишессерита - на 5 ат. в формуле.

Note. Hereinafter the mineral composition is performed by means of MIRA LM electron microscope (IGM SB RAS, Novosibirsk). A dash - not found. The formula of hessite is calculated for 3 atoms; altaite and clausthalite - for 2 atoms, and petzite and fischesserite - for 5 atoms. 

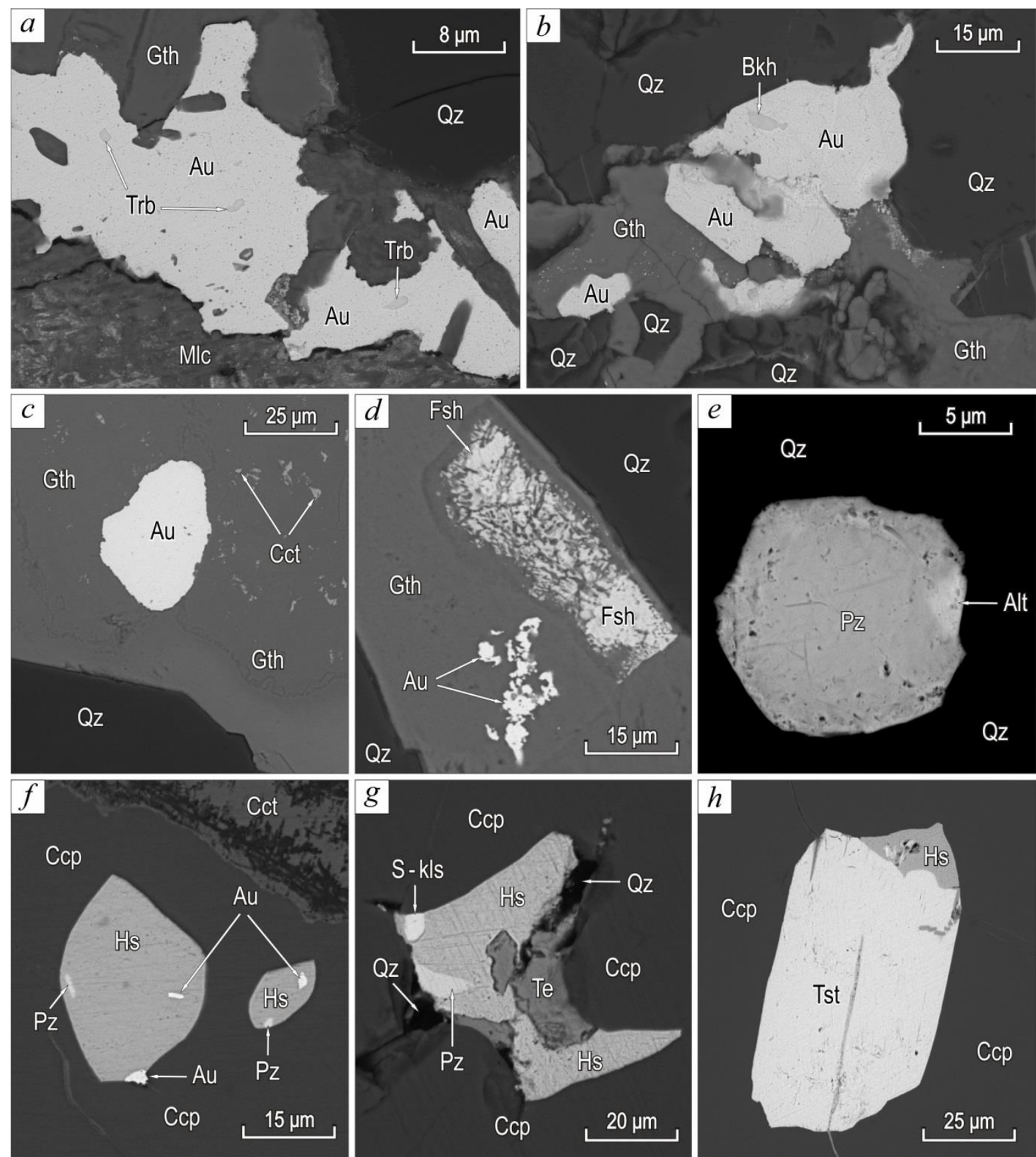

Pис. 5. Золото золото-теллуридно-сульфидно-квариевых жил в кварие (Qz), халькопирите (Сср), гётите (Gth) c теллуровисмутитом (Trb), малахитом (Mlc), букхорнитом (Bkh), халькозином (Cct), фишессеритом (Fsh), петцитом (Pz), алтаитом (Alt), гесситом (Hs), серосодержащим клаусталитом (S-Kls), самородным теллуром (Te) и иумоитом (Tst). Изображение в обратно-рассеянных электронах

Fig. 5. Gold in Au-telluride-sulfide-quartz veins in quartz ( $Q z)$, chalcopyrite (Ccp), goethite (Gth) with tellurobismuthite $(T r b)$, malachite (Mlc), bukhornite (Bkh), chalcocite (Cct), fischesserite (Fsh), petzite (Pz), altaite (Alt), hessite (Hs), $S$-clausthalite (S-Kls), native tellurium (Te) and tsumoite (Tst). BSE image

Таблица 2. Химический состав букхорнита (бакхорнита) (мас. \%)

Table 2. Chemical composition of bukhornite (wt. \%)

\begin{tabular}{|c|c|c|c|c|c|c|c|}
\hline $\begin{array}{c}\text { Анализ } \\
\text { Analysis }\end{array}$ & $\mathrm{Pb}$ & $\mathrm{Bi}$ & $\mathrm{S}$ & $\mathrm{Au}$ & $\mathrm{Te}$ & $\begin{array}{c}\text { Cумма } \\
\text { Total }\end{array}$ & $\begin{array}{c}\text { Формула } \\
\text { Formula }\end{array}$ \\
\hline 1 & 33,53 & 17,14 & 8,93 & 17,17 & 22,85 & 99,62 & $\left(\mathrm{~Pb}_{1,85} \mathrm{Bi}_{0,94} \mathrm{~S}_{3,18}\right)_{5,97}\left(\mathrm{Au}_{0,99} \mathrm{Te}_{2,04}\right)_{3,04}$ \\
\hline 2 & 38,01 & 14,27 & 8,25 & 17,85 & 21,27 & 99,65 & $\left(\mathrm{~Pb}_{2,16} \mathrm{Bi}_{0,80} \mathrm{~S}_{3,02}\right)_{5,98}\left(\mathrm{Au}_{1,06} \mathrm{Te}_{1,96}\right)_{3,02}$ \\
\hline 3 & 38,33 & 14,61 & 7,79 & 17,37 & 21,29 & 99,39 & $\left(\mathrm{~Pb}_{2,21} \mathrm{Bi}_{0,8} \mathrm{~S}_{2,91}\right)_{5,96}\left(\mathrm{Au}_{1,05} \mathrm{Te}_{1,99}\right)_{3,04}$ \\
\hline 4 & 36,45 & 15,60 & 8,36 & 16,30 & 22,96 & 99,67 & $\left(\mathrm{~Pb}_{2,05} \mathrm{Bi}_{0,87} \mathrm{~S}_{3,03}\right)_{5,95}\left(\mathrm{Au}_{0,96} \mathrm{Te}_{2,09}\right)_{3,05}$ \\
\hline
\end{tabular}

Примечание. Формула минерала рассчитана на 9 ат.

Note. The mineral formula is calculated for 9 atoms. 
В коре выветривания развиты гипергенные минералы $\mathrm{Cu}, \mathrm{Fe}, \mathrm{Pb}, \mathrm{As}, \mathrm{Bi}$ (чеховичит $\mathrm{Bi}_{2} \mathrm{Te}_{4} \mathrm{O}_{11}$, бисмутит $\left.\mathrm{Bi}_{2} \mathrm{O}_{2}\left(\mathrm{CO}_{3}\right)\right)$, гипергенное серебро $\mathrm{Ag}$, акантит $\mathrm{Ag}_{2} \mathrm{~S}$ и ютенбогаардтит $\mathrm{Ag}_{3} \mathrm{AuS}_{2}$. Гипергенные минералы $\mathrm{Ag}$ и Аu в виде зерен (до 35 мкм) сложной формы выявлены только в окисленных рудах среди гидроксидов $\mathrm{Fe}$, что предполагает их гипергенное происхождение. Состав (мас. \%) ютенбогаардтита: Au 33,25-33,46; Ag 54,06-55,18; S 11,31-11,34; акантита: Ag 86,96; S 12,94.

\section{Условия образования березитов и рудных жил}

Термобарогеохимические исследования флюидных включений проведены в ЦКП «Многоэлементные и изотопные исследования» СО РАН (г. Новосибирск) и лаборатории термобарогеохимии ЮжноУральского госуниверситета (г. Миасс) согласно опубликованным методикам [6, 7]. Давление захвата флюидных включений рассчитано посредством программы FLINCOR с использованием температур гомогенизации $\mathrm{CO}_{2}$. Обработка результатов выполнена в программе Statistica 12.

В кварце березитов (обр. АРБ-68) проанализированы, согласно классификации Э. Рёддера [8], псевдовторичные и вторичные флюидные включения. По фазовому составу выделяются трехфазные (VLS) включения, содержащие твердую, жидкую и газовую фазы, и двухфазные газово-жидкие (VL) включения. Псевдовторичные VLS включения имеют удлиненную форму с неровными краями и размеры до 15 мкм. Твердая минеральная фаза включений светлоокрашенная, изотропная, кубического габитуса, предположительно, представлена $\mathrm{NaCl}$. Газовая фаза, согласно данным рамановской спектроскопии, представлена углекислотой. Температуры гомогенизации трехфазных включений варьируют от 320 до $340{ }^{\circ} \mathrm{C}$. Концентрации солей в псевдовторичных VLS включениях отмечаются от 39,8 до 41,5 мас. $\% \mathrm{NaCl}$-экв.

Псевдовторичные VL включения имеют изометричную форму и размеры 6-10 мкм, в отдельных случаях наблюдаются элементы кристаллографических граней. В составе газовой фазы обнаружены следы $\mathrm{CO}_{2}$. Соленость включений, установленная по температурам плавления льда $\left(\mathrm{T}_{\text {пл }}\right)-3.8 \ldots-3{ }^{\circ} \mathrm{C}$, составляет 4,9-6,1 мас. \% NaCl-экв. Температуры гомогенизации (в жидкость) составили $250-320^{\circ} \mathrm{C}$.

Вторичные VL включения образуют «сетку» по всему исследуемому образцу. Они имеют округлую форму и размеры до 6 мкм. Для них получены температуры гомогенизации (в жидкость) $110-180{ }^{\circ} \mathrm{C}$ (табл. 3, рис. 6).

В кварце золотоносных жил в березитах изучались первичные и псевдовторичные включения. По фазовому составу среди них выделены следующие генерации: 1) VLS, содержащие газовую, жидкую и твердую фазы; 2) VLC, в которых различаются жидкая углекислота, водно-солевой раствор и газовая фаза; 3) $\mathrm{VL}-$ с жидкой и газовой фазами (рис. 7).

В кварце (обр. АР-19) золото-сульфиднокварцевых жил наблюдаются первичные VLC и псевдовторичные VLS и VL флюидные включения. Первичные VLC включения имеют удлиненную или округлую форму и размеры от 5 до 10 мкм. Температуры гомогенизации $\mathrm{CO}_{2}$ в газ составили $28-28,3{ }^{\circ} \mathrm{C}$, а температуры полной гомогенизации в жидкость 270-280 ${ }^{\circ} \mathrm{C}$. Эти данные позволили оценить давление захвата около 1800 бар и рассчитать плотность $\mathrm{CO}_{2} \approx 0,29 \mathrm{r} / \mathrm{cm}^{3}$. Трехфазные включения с твердой минеральной фазой (VLS) содержат светлую, изотропную минеральную фазу кубической морфологии, которая, предположительно, представлена $\mathrm{NaCl}$. В газовой фазе содержится углекислота. Концентрации солей в этих включениях составили 31,9-32,9 мас. \% $\mathrm{NaCl}$-экв., температуры их гомогенизации $200-220{ }^{\circ} \mathrm{C}$. Доля газовой фазы в двухфазных VL включениях около 25 об. \% и представлена углекислотой. Температуры гомогенизации (в жидкость) образуют интервал $145-210^{\circ} \mathrm{C}$.

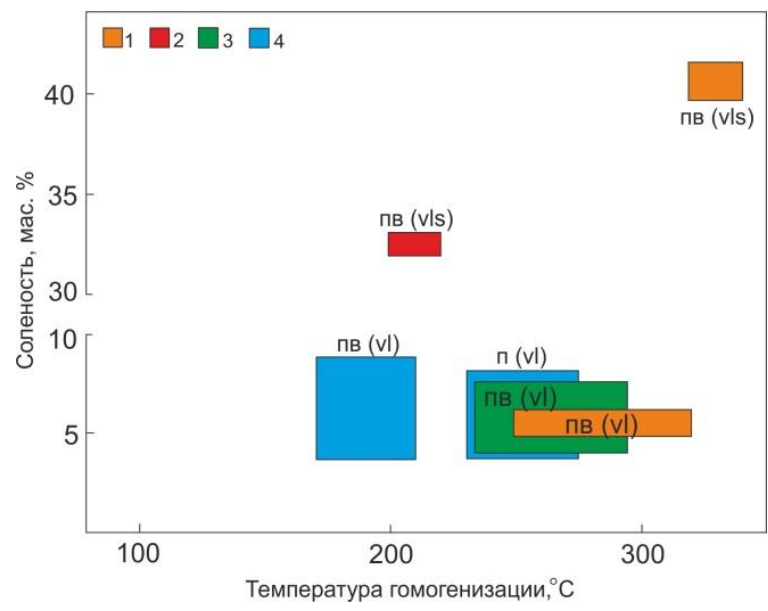

Pис. 6. Температуры гомогенизации и соленость флюидных включений в кварие рудопроявления Арыскан: 1 - березиты; 2-3 - ранние золотосульфидно-квариевые жиль; 4 - поздние золототеллуридно-сульфидно-квариевые жилы. Буквами обозначены генерачия и фазовый состав включений (прим. к табл. 3)

Fig. 6. Homogenization temperatures vs salinity of fluid inclusions in quartz from Aryskan ore occurrence: 1 - berezites; 2-3 - early gold-sulfide-quartz veins; 4 - late gold-telluride-quartz veins. The letters indicate the association and phase composition of inclusions (note to table 3)

Псевдовторичные VLS включения в кварце (обр. AР-62, АРР-62) золото-сульфидно-кварцевой жилы характеризуются изометричной формой и размерами 5-15 мкм. Газовая фаза представлена углекислотой. Tpехфазные (VLS) включения содержат светлоокрашенную, изотропную минеральную фазу, диагностированную как $\mathrm{NaCl}$. Температуры гомогенизации этих включений не были получены вследствие их декрепитации при температурах $260-280^{\circ} \mathrm{C}$.

Псевдовторичные VL включения имеют размеры до 5-10 мкм, кристаллографические очертания и размеры газовых вакуолей до 20-30 \% объема включения. Температуры эвтектики образуют диапазон значений от $-23,1$ до $-23,9{ }^{\circ} \mathrm{C}$, отвечающий $\mathrm{NaCl}-\mathrm{KCl}$ $\mathrm{H}_{2} \mathrm{O}$ составу флюида. $\mathrm{T}_{\text {пл }}$ отмечаются от $-2,5$ до $4,7^{\circ} \mathrm{C}$, а соленость в соответствии с ними - от 4 до 
7,5 мас. \% NaCl-экв. Часть этих включений гомогенизируется в газ при температурах от 230 до $290{ }^{\circ} \mathrm{C}$, а часть, одновременно с ними, в жидкость - в интервале температур от 245 до $280{ }^{\circ} \mathrm{C}$. Это является призна- ком гетерогенизации флюида, что позволяет считать данный интервал $\left(230-290{ }^{\circ} \mathrm{C}\right)$ истинными температурами минералообразования, а также может быть причиной отложения золота в жилах $[8,9]$.

Таблица 3. Результаты изучения флюидных включений в кварие рудопроявления Арыскан

Table 3. Summarized fluid inclusion data of Aryskan ore occurrence

\begin{tabular}{|c|c|c|c|c|c|c|c|c|c|c|}
\hline 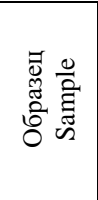 & 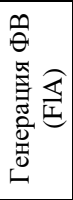 & 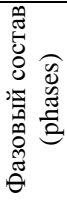 & $\begin{array}{l}\mathrm{T}_{\text {гом }},{ }^{\circ} \mathrm{C} \\
\mathrm{T}_{\text {hom }},{ }^{\circ} \mathrm{C}\end{array}$ & $\left|\begin{array}{c}\mathrm{T}_{\text {гом. }} \mathrm{CO}_{2} \\
{ }^{\circ} \mathrm{C} \\
T_{\text {hom }} \\
\mathrm{CO}_{2},{ }^{\circ} \mathrm{C}\end{array}\right|$ & $\begin{array}{l}\mathrm{T}_{\text {эвт }},{ }^{\circ} \mathrm{C} \\
\mathrm{T}_{\text {eut }},{ }^{\circ} \mathrm{C}\end{array}$ & $\begin{array}{l}\mathrm{T}_{\text {пл. льда, }},{ }^{\circ} \mathrm{C} \\
\mathrm{T}_{\text {ice melt }},{ }^{\circ} \mathrm{C}\end{array} \mid$ & $\begin{array}{c}\text { Соленость } \\
\text { (мас. \% } \\
\mathrm{NaCl}-э \text { эв.) } \\
C \text {, wt. \%, } \\
\mathrm{NaCl} \text { equiv }\end{array}$ & $\mid \begin{array}{c}\mathrm{D}, \\
\Gamma / \mathrm{cm}^{3} \\
\mathrm{D}, \\
\mathrm{g} / \mathrm{cm}^{3}\end{array}$ & $\begin{array}{c}\mathrm{P} \\
\text { бар } \\
\mathrm{P}, \text { bar }\end{array}$ & $\begin{array}{l}\text { Солевой состав } \\
\text { Salt composition }\end{array}$ \\
\hline \multicolumn{11}{|c|}{ Березиты/Berezites } \\
\hline \multirow{3}{*}{ АРБ-68 } & ПВ & VLS & $320-340$ & - & - & - & $39,8-41,5$ & - & - & Хлориды/chloride+CO $\mathrm{CO}_{2}$ (газ/gas) \\
\hline & ПВ & VL & $250-320$ & - & - & $-3,8 \ldots-3$ & $4,9-6,1$ & - & - & $+\mathrm{CO}_{2}$ (газ/gas) \\
\hline & $\mathrm{B}$ & $\mathrm{VL}$ & $110-180$ & - & - & - & - & - & - & - \\
\hline \multicolumn{11}{|c|}{ Золото-сульфидно-кварцевые жилы/Gold-sulfide-quartz veins } \\
\hline \multirow{3}{*}{ AP-19 } & $\Pi$ & VLC & $270-280$ & \begin{tabular}{|l|}
$28-28,3$ \\
\end{tabular} & - & - & - & 0,29 & 1800 & $+\mathrm{CO}_{2}$ (га3/gas+liquid) \\
\hline & ПВ & VLS & $200-220$ & - & - & - & $31,9-32,9$ & - & - & Хлориды/chloride+CO $\mathrm{CO}_{2}$ (газ/gas) \\
\hline & ПВ & VL & $145-210$ & - & - & - & - & - & - & $+\mathrm{CO}_{2}$ (га3/gas) \\
\hline \multirow[b]{2}{*}{$\begin{array}{l}\text { AP-62, } \\
\text { APP-62 }\end{array}$} & ПВ & VLS & $260-280^{*}$ & - & - & - & - & - & - & $+\mathrm{CO}_{2}$ (газ/gas) \\
\hline & ПВ & VL & $\begin{array}{c}230-290 \text { (в газ) } \\
245-280 \\
\text { (в жидкость) }\end{array}$ & - & $-23,1 \ldots-23,9$ & $-2,5 \ldots-4,8$ & $4,1-7.5$ & - & - & $\mathrm{NaCl}-\mathrm{KCl}-\mathrm{H}_{2} \mathrm{O}+\mathrm{CO}_{2}$ (газ/gas) \\
\hline \multicolumn{11}{|c|}{ Золото-теллуридно-сульфидно-кварцевые жилы/Gold-telluride-sulfide-quartz veins } \\
\hline \multirow[t]{2}{*}{$\begin{array}{c}\text { AP-57, } \\
\text { AP-60 }\end{array}$} & $\Pi$ & VL & $200-270$ & - & $-22,8 \ldots-23,9$ & $-2,3 \ldots-5$ & $4-8,5$ & - & - & $\begin{array}{c}\mathrm{NaCl}-\mathrm{KCl}-\mathrm{H}_{2} \mathrm{O} \\
\mathrm{NaCl}-\mathrm{Na}_{2} \mathrm{HCO}_{4}-\mathrm{H}_{2} \mathrm{O}+\mathrm{CO}_{2} \text { (газ/gas) } \\
\end{array}$ \\
\hline & ПВ & VL & $160-200$ & - & -21 & $-1,7 \ldots-5,0$ & $2,9-7,8$ & - & - & $\mathrm{NaCl}-\mathrm{H}_{2} \mathrm{O}$ \\
\hline
\end{tabular}

Примечание. Включения: П-первичные, ПВ-псевдовторичные, $B$ - вторичные; VLS-трехфазные газово-жидкие c твердой фазой; VLC - трехфазные газово-жидкие с углекислотой; VL - двухфазные газово-жидкие. $T_{\text {гом }}-$ температура гомогенизации, $T_{\text {гом }} \mathrm{CO}_{2}-\mathrm{T}$ гомогенизачии $\mathrm{CO}_{2}, T_{\text {эт }}$ - температура эвтектики, $T_{n л}$ - температура плавления последнего кристалла льда, $d$-плотность $\mathrm{CO}_{2}$. Прочерк - не определено. * - температуры декрепитации.

Note. $\Pi$ - primary inclusions, $\Pi B$ - pseudosecondary inclusions, $B$ - secondary inclusions, $T_{\text {hom }}-$ homogenization temperatures, $T_{\text {hom }} \mathrm{CO}_{2}-\mathrm{CO}_{2}$ homogenization temperatures, $T_{\text {eut }}$-eutectic temperatures; $T_{\text {ice melt }}-$ final melting temperatures, $d-$ $\mathrm{CO}_{2}$ density. A dash - not determined.

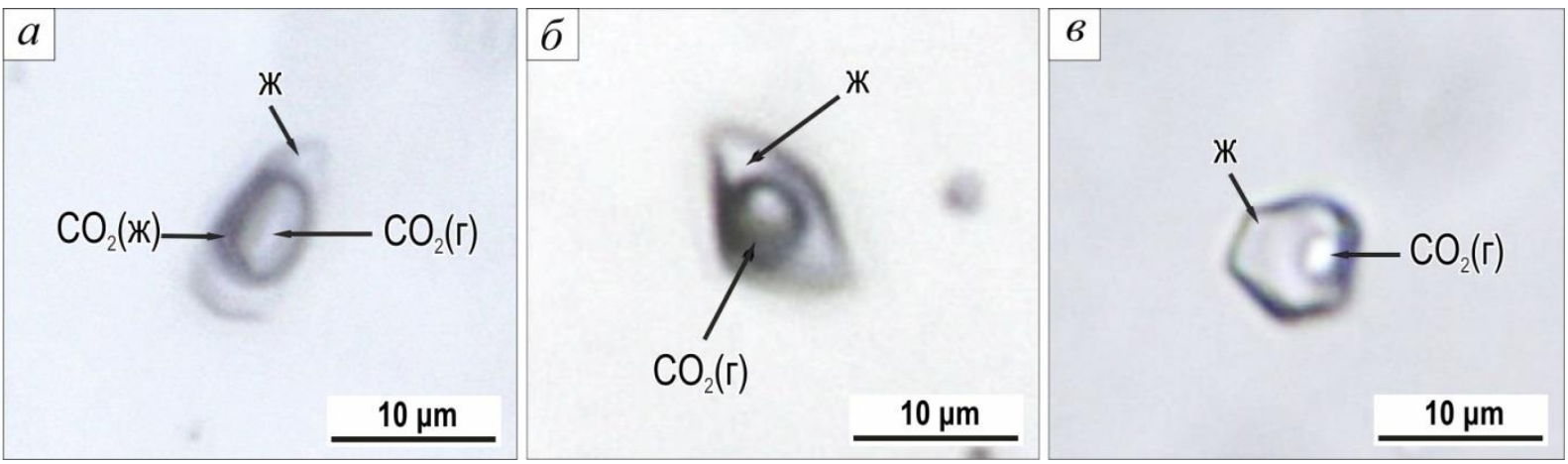

Рис. 7. Флюидные включения в кварие рудопроявления Арыскан: а, б) первичные: а) VLC (AP-19); б) VL (AP-57); в) псевдовторичное VL (AP-19)

Fig. 7. Fluid inclusions in quartz from Aryskan ore occurrence: a, б) primary: a) VLC (AP-19), б) VL (AP-57); в) pseudosecondary VL (AP-19)

В кварце золото-теллуридно-сульфиднокварцевых жил (обр. АР-57, АР-60) выделены две генерации двухфазных (VL) флюидных включений: первичные и псевдовторичные. Первичные включения имеют изометричную или удлиненную форму и размеры 10-12 мкм. Газовая фаза занимает около 10 об. \% включения и представлена $\mathrm{CO}_{2}$. Происходит эвтектика в интервале от $-22,8$ до $-23,9^{\circ} \mathrm{C}$, что отвечает $\mathrm{NaCl}-\mathrm{KCl}-\mathrm{H}_{2} \mathrm{O}$ флюиду. $\mathrm{T}_{\text {пл }}-5.5 . .-5^{\circ} \mathrm{C}$ соответствуют концентрациям солей 7,8-8,5 мас. \% $\mathrm{NaCl}$-экв.
Температуры гомогенизации (в жидкость) составили $230-270{ }^{\circ} \mathrm{C}$.

Псевдовторичные VL включения имеют изометричную форму и размеры до 5 мкм. Доля газовой фазы достигает 20 об. \%. Концентрации солей составили $3,3-4,9$ мас. \% NaCl-экв. согласно $\mathrm{T}_{\text {пл }}-3 \ldots-2{ }^{\circ} \mathrm{C}$. Температуры гомогенизации (в жидкость) составили 160-200 ${ }^{\circ} \mathrm{C}$. Из-за малого размера включений температура эвтектики была определена только в единичных случаях $\left(-21{ }^{\circ} \mathrm{C}\right)$, что отвечает $\mathrm{NaCl}-\mathrm{H}_{2} \mathrm{O}$ флюиду. 
Таблица 4. Валовый состав растворов флюидных включений в кварие Арысканского рудопроявления

Table 4. Bulk fluid inclusion composition in quartz from Aryskan ore occurrence

\begin{tabular}{|c|c|c|c|}
\hline \multirow[b]{2}{*}{ 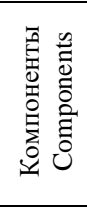 } & \multicolumn{2}{|c|}{ Кварц/Quartz } & \multirow[b]{2}{*}{ 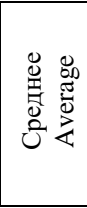 } \\
\hline & $\begin{array}{c}\text { Золото-сульфидно- } \\
\text { кварцевые жилы } \\
\text { Au-sulfide-quartz } \\
\text { veins }\end{array}$ & $\begin{array}{c}\text { Золото-теллуридно- } \\
\text { сульфидно-кварцевые } \\
\text { жилы } \\
\text { Au-telluride-sulfide-quartz } \\
\text { veins }\end{array}$ & \\
\hline \multicolumn{4}{|c|}{$\begin{array}{l}\text { Макрокомпоненты, г/кг воды } \\
\text { Bulk components, } \mathrm{g} / \mathrm{kg} \mathrm{H}_{2} \mathrm{O}\end{array}$} \\
\hline $\mathrm{CO}_{2}$ & 85,58 & 23,98 & 54,78 \\
\hline $\mathrm{CH}_{4}$ & 0,196 & 0,196 & 0,20 \\
\hline $\mathrm{HCO}_{3}{ }^{-}$ & 35,74 & 37,59 & 36,67 \\
\hline $\mathrm{Cl}^{-}$ & 4,51 & 4,27 & 4,39 \\
\hline $\mathrm{Na}$ & 12,91 & 13,82 & 13,36 \\
\hline $\mathrm{Ca}$ & 1,96 & 1,74 & 1,85 \\
\hline $\mathrm{K}$ & 1,32 & 0,53 & 0,92 \\
\hline $\mathrm{Mg}$ & 0,255 & 0,446 & 0,35 \\
\hline $\mathrm{Na} / \mathrm{K}$ & 9,78 & 26,07 & 14.52 \\
\hline \multicolumn{4}{|c|}{$\begin{array}{c}\text { Микрокомпонентыл, } 10^{-3} \text { г/кг воды } \\
\text { Trace elements, } 10^{-3} \mathrm{~g} / \mathrm{kg} \mathrm{H} \mathrm{H}_{2} \mathrm{O}\end{array}$} \\
\hline $\mathrm{B}$ & 696,31 & 206,14 & 451,22 \\
\hline $\mathrm{Sr}$ & 82,27 & 62,94 & 72,60 \\
\hline $\mathrm{Ba}$ & 153,19 & 350,46 & 251,82 \\
\hline $\mathrm{Cu}$ & 780,13 & 47,45 & 413,79 \\
\hline $\mathrm{Zn}$ & 58,48 & 11,76 & 35,12 \\
\hline As & 208,87 & 101,02 & 154,95 \\
\hline $\mathrm{Sb}$ & 27,87 & 0,00 & 13,94 \\
\hline $\mathrm{Mn}$ & 42,68 & 35,07 & 38,88 \\
\hline $\mathrm{Fe}$ & 9,17 & 18,61 & 13,89 \\
\hline Mo & 10,89 & 2,89 & 6,89 \\
\hline $\mathrm{Li}$ & 3,72 & 3,48 & 3,60 \\
\hline $\mathrm{Rb}$ & 2,17 & 0,79 & 1,48 \\
\hline $\mathrm{Pb}$ & 1,18 & 0,19 & 0,68 \\
\hline Cs & 0,61 & 0,43 & 0,52 \\
\hline $\mathrm{Ge}$ & 0,07 & 0,15 & 0,11 \\
\hline $\mathrm{Cd}$ & 0,66 & 0,21 & 0,44 \\
\hline $\mathrm{Au}$ & 0,17 & 0,11 & 0,14 \\
\hline $\mathrm{Ag}$ & 0,21 & 3,12 & 1,67 \\
\hline $\mathrm{Bi}$ & 0,01 & 0,01 & 0,01 \\
\hline W & 9,07 & 0,00 & 4,54 \\
\hline Sn & 0,00 & 0,68 & 0,34 \\
\hline $\mathrm{Hg}$ & 0,58 & 0,00 & 0,29 \\
\hline $\mathrm{Tl}$ & 0,00 & 0,12 & 0,06 \\
\hline Co & 0,35 & 0,45 & 0,40 \\
\hline $\mathrm{Ni}$ & 20,38 & 1,45 & 10,92 \\
\hline $\mathrm{Cr}$ & 0,00 & 0,93 & 0,47 \\
\hline $\mathrm{V}$ & 0,00 & 0,00 & 0,00 \\
\hline $\mathrm{U}$ & 0,01 & 0,00 & 0,01 \\
\hline $\mathrm{K} / \mathrm{Rb}$ & 608 & 670 & 620 \\
\hline $\begin{array}{c}\mathrm{CO}_{2} / \mathrm{C} \\
\mathrm{H}_{4} \\
\end{array}$ & 439 & 122 & 280 \\
\hline
\end{tabular}

Примечание. Анализы выполнены в ФГУП ЦНИГРИ (аналитик С.Г. Кряжев). Прочерк - содержание ниже предела обнаружения.

Note. The analyses were performed in FSBI TSNIGRI (operator S.G. Kryazhev). A dash - below the detection limit.

\section{Геохимические особенности флюидов}

Газовый состав флюида, содержание анионов, катионов и микроэлементов проанализированы в выше указанных приборах по методике [10] в ЦНИГРИ (г. Москва).

Рудообразующий флюид, отложивший золотосульфидно-кварцевые жилы, рудопроявления Арыскан характеризуется многокомпонентным составом (табл. 4). Среди катионов главную роль играет (г/кг $\left.\mathrm{H}_{2} \mathrm{O}\right) \mathrm{Na}(12,91)$, в подчиненном количестве находятся $\mathrm{Ca}(1,96), \mathrm{K}(1,32)$, и $\mathrm{Mg}(0,26)$. Растворенных газов в рудообразующем флюиде много, и среди них преобладала углекислота. Установлены значимые количества таких компонентов, как $\left(г / к г \mathrm{H}_{2} \mathrm{O}\right): \mathrm{CO}_{2}(85,6)$, $\mathrm{HCO}_{3}{ }^{-}(35,74), \mathrm{Cl}^{-}(4,51)$ и $\mathrm{CH}_{4}(0,20)$. Из микрокомпонентов в значительных количествах присутствует $\left(10^{-3}\right.$ г/кг $\left.\mathrm{H}_{2} \mathrm{O}\right): \mathrm{Cu}(780), \mathrm{B}(696)$, As (209), Ba (153), $\mathrm{Sb}(27,9)$ и другие, в небольших количествах - $\mathrm{Pb}$ $(1,18), \mathrm{Hg}(0,58), \mathrm{Ag}(0,21), \mathrm{Au}(0,17), \mathrm{Bi}$ и U $(0,01)$ и др. (табл. 4).

Отношения главных компонентов флюида изменяются в следующих пределах: $\mathrm{Na} / \mathrm{K}$ - от 26,07 до 9,78, $\mathrm{CO}_{2} / \mathrm{CH}_{4}$ - от 122 до 439.

Во флюиде, отложившем золото-теллуридносульфидно-кварцевые жилы, среди катионов главную роль играет (г/кг $\left.\mathrm{H}_{2} \mathrm{O}\right) \mathrm{Na}(13,82)$, в подчиненном количестве находятся Са $(1,74), \mathrm{K}(0,53)$, и $\mathrm{Mg}(0,45)$. Установлены значимые количества (г/кг $\left.\mathrm{H}_{2} \mathrm{O}\right): \mathrm{CO}_{2}$ $(23,98), \mathrm{HCO}_{3}^{-}(37,59), \mathrm{Cl}^{-}(4,27)$ и $\mathrm{CH}_{4}(0,20)$. Из микрокомпонентов присутствует $\left(10^{-3}\right.$ г/кг $\left.\mathrm{H}_{2} \mathrm{O}\right): \mathrm{Ba}$ (350,5), B (206,1), As (101), Sr (62,9), Cu (47,5), Fe $(18,61), \mathrm{Zn}(11,8), \mathrm{Ag}(3,12)$, Mo $(2,89), \mathrm{Ni}(1,45), \mathrm{Cr}$ $(0,93), \mathrm{Pb}(0,19), \mathrm{Au}(0,11), \mathrm{Bi}(0,01)$ и др. (табл. 4).

Средний химический состав рудообразующих флюидов показан на рис. 8 .

\section{Изотопный состав серы пирита и флюида}

Определение отношений стабильных изотопов серы в пирите выполнено в ЦКП «Многоэлементные и изотопные исследования» СО РАН с использованием газового масс-спектрометра Finnigan MAT Delta в режиме двойного напуска (г. Новосибирск, аналитики В.Н. Реутский, М.Н. Колбасова). Значения $\delta^{34} \mathrm{~S}$ приведены в промилле (\%о) относительно стандарта CDT.

Для определения изотопного состава сульфидной серы были отобраны монофракции двух проб пирита из золото-теллуридно-сульфидно-кварцевых жил. Изотопный состав пирита характеризуется от $+1,6$ до $+2,5 \%$. Изотопный состав серы сульфидов гидротермальных месторождений зависит от источника серы гидротермальной жидкости и условий осаждения минерала (температура осаждения, $\mathrm{pH}$ и $\mathrm{fO}_{2}$ и т. д.) [11-13].

Значения $\delta^{34} \mathrm{~S}_{\mathrm{H}_{2} \mathrm{~S}}$ флюида в соответствии с уравнением фракционирования $[11,14]$, варьируют от $-0,5$ до $1,1 \%$ при $270-160{ }^{\circ} \mathrm{C}$, что свидетельствует об участии серы магматического происхождения (от -3 до +3\%o) $[11,12]$.

\section{Обсуждение результатов}

Золотое оруденение на рудопроявлении Арыскан парагенетически связано с дайками риолит- и гранодиоритов-порфиров баянкольского комплекса $\left(\mathrm{D}_{3}\right)$ и сопряжено с процессами березитизации интрузивных и осадочных пород. Отметим, что образование березитов с кварцем, пиритом, серицитом, анкеритом и сидеритом по интрузивным (кислым, средним) и осадочным, вулканогенно-осадочным породам описано на Мечниковском, Ганеевском (Южный Урал) и Кедровом (Забайкалье) месторождениях [15-19]. 


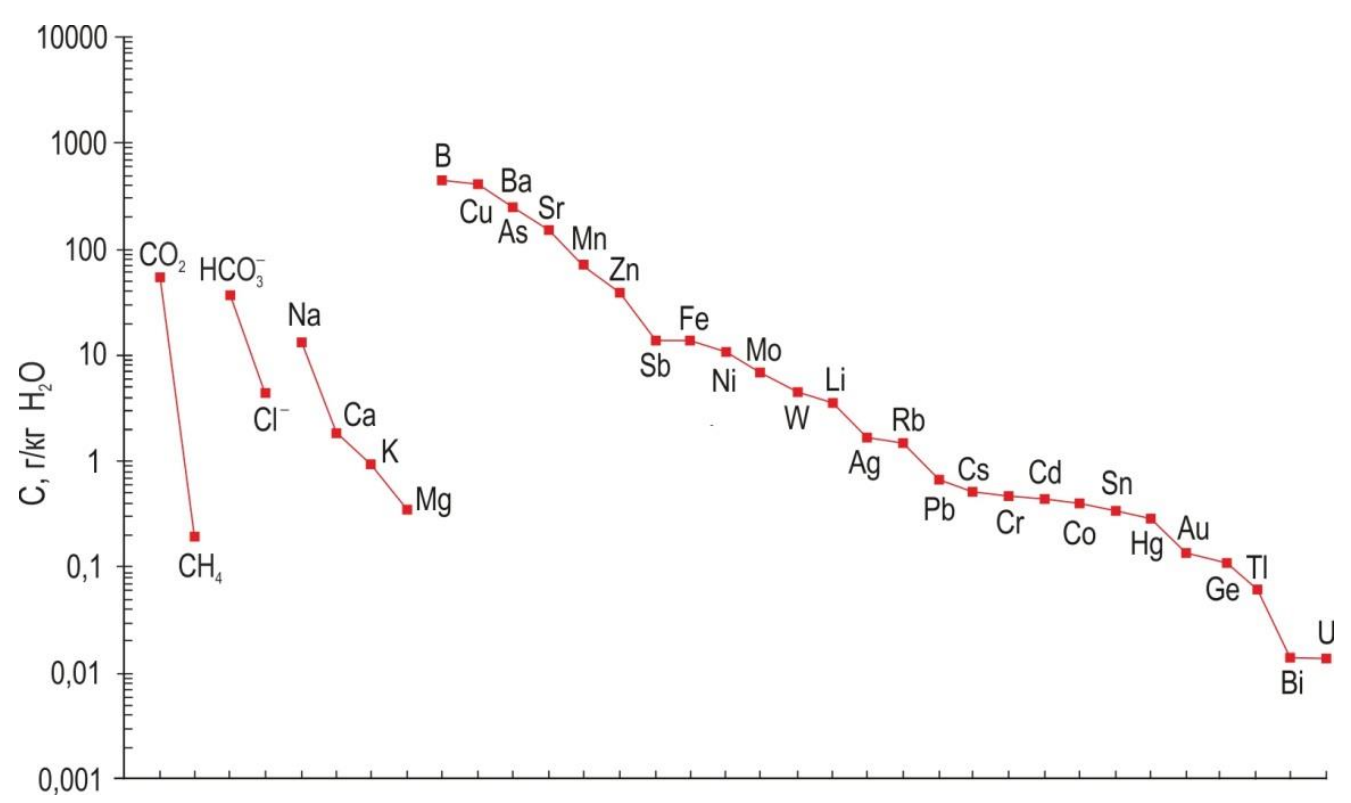

Рис. 8. Средний химический состав флюида рудопроявления Арыскан

Fig. 8. Average chemical fluid composition of Aryskan ore occurrence

Рудопроявление Арыскан характеризуется своеобразным минеральным составом руд, а именно наличием теллуридов (петцит, гессит, теллуровисмутит, цумоит, алтаит), селенидов (фишессерит, клаусталит) и сульфотеллурида $\mathrm{Au}$ (букхорнит), последние характерны для вулканогенно-гидротермальных золотосеребрянных, вулканогенно-плутоногенных золотокварцевых месторождений [20].

Минералого-геохимическими методами установлено, что средняя проба золота рудопроявления Арыскан составляет 894 \%о при вариациях от 810 до $935 \%$, золото-сульфидно-кварцевой стадии - $893 \%$ (от 810 до $935 \%$ ), золото-теллуридно-сульфиднокварцевой стадии - $900 \%$ (866-925\%), т. е. золотины золотосодержащих минеральных ассоциаций рудопроявления сходны и характеризуются с небольшой дисперсией.

По данным ICP-MS, среди анионов в рудообразующем флюиде преобладает гидрокарбонат, концентрации которого существенно выше хлора. Из катионов рудообразующий флюид наиболее обогащен $\mathrm{Na}$ c примесями $\mathrm{Ca}, \mathrm{K}$ и $\mathrm{Mg}$; и флюид можно отнести к гидрокарбонатно-хлоридно-натриевому типу, что не противоречит данным термометрии. Повышенные количества $\mathrm{Ca}, \mathrm{Mg}$ и $\mathrm{Ba}( \pm \mathrm{Sr}, \mathrm{Mn})$ и гидрокарбонатиона выражаются в отложении карбонатов во вмещающих березитах.

Обогащение флюида рудными элементами $(\mathrm{Cu}, \mathrm{Zn}$, $\mathrm{As}, \mathrm{Sb})$ отражает состав сульфидов золотосодержащих минеральных ассоциаций. Высокие концентрации $\mathrm{Cu}$ во флюиде выражены в широком развитии халькопирита в жилах.

Согласно данным рамановской спектроскопии флюидных включений, золотосодержащие жилы и метасоматиты рудопроявления Арыскан отлагались метан-углекислотно-водно-хлоридным флюидом. В процессе минералообразования от ранних жил к поздним наблюдается снижение доли $\mathrm{CO}_{2}$ во флюиде.
На заключительных стадиях минералообразования флюид представлен водно-солевым раствором с повышенными содержаниями $\mathrm{Ba}$ и $\mathrm{Ag}$, что согласуется с минералогическими данными (наличием барита и теллуридов Ag). Степень окисленности флюида $\left(\mathrm{CO}_{2} / \mathrm{CO}_{2}+\mathrm{CH}_{4}\right)$ при минералообразовании стабильна и составляет 0,9-1. На окисленный характер флюида указывает также присутствие в жилах селенидов и $\mathrm{Se}-$ содержащих минералов, т. к., по данным [21], развитие селенидов в рудах свидетельствует о высоком окислительном потенциале среды рудообразования.

По результатам термометрии флюидных включений, березиты образовались при участии углекислотноводно-хлоридного флюида с соленостью 4,9-41,5 мас. \% экв. $\mathrm{NaCl}$ при минимальных температурах $250-340^{\circ} \mathrm{C}$.

Ранние золото-сульфидно-кварцевые жилы образовались при $\mathrm{P} \sim 1,8$ кбар ( $\sim 5,4$ км) из флюида состава $\mathrm{NaCl}-\mathrm{KCl}_{2} \mathrm{H}_{2} \mathrm{O} \pm \mathrm{CO}_{2}$ с концентрациями солей $4,1-32,9$ мас. \% $\mathrm{NaCl}$-экв. при температурах $145-290{ }^{\circ} \mathrm{C}$.

Золото-теллуридно-сульфидно-кварцевые жилы образованы углекислотно-водным флюидом состава $\mathrm{NaCl}-\mathrm{KCl}-\mathrm{H}_{2} \mathrm{O}, \quad \mathrm{NaCl}-\mathrm{Na}_{2} \mathrm{HCO}_{4}-\mathrm{H}_{2} \mathrm{O}$ и $\mathrm{NaCl}-\mathrm{H}_{2} \mathrm{O}$ с концентрациями солей 2,9-8,5 мас. \% $\mathrm{NaCl}-$ экв. при температурах $145-290{ }^{\circ} \mathrm{C}$. Отметим, что параметры формирования парагенезисов $\mathrm{Ag}_{3} \mathrm{AuTe}_{2}-\mathrm{Ag}_{2} \mathrm{Te}-\mathrm{Au}$ соответствуют $128-280{ }^{\circ} \mathrm{C}$, при $f\left(\mathrm{Te}_{2}\right)=10^{-13}-10^{-10}$ [21].

Парагенезис золота в золото-сульфиднокварцевых жилах с пиритом, халькопиритом и галенитом предполагает то, что фугитивность серы $\left(f \mathrm{~S}_{2}\right)$ в минералообразующей системе составляла от $10^{-14,3}$ до $10^{-8,6}$ при $250{ }^{\circ} \mathrm{C}[22,23]$. Парагенезис теллуридов, сульфидов и селенидов в золото-теллуридносульфидно-кварцевых жилах образовался при фугитивности теллура (fTе $\left.\mathrm{Te}_{2}\right)$ от $10^{-17,9}$ до $10^{-9,5}, f \mathrm{~S}_{2}-10$ ${ }^{23,5}-10^{-9,5}, \mathrm{Se}_{2}-10^{21,2}-10^{-18,5}$ при $200^{\circ} \mathrm{C}[22,23]$.

Изотопные значения $\delta^{34} \mathrm{~S}_{\mathrm{H}_{2} \mathrm{~S}}$ флюида (от $-0,5$ до $1,1 \%$, при $\left.270-160{ }^{\circ} \mathrm{C}\right)$ свидетельствуют о магматиче- 
ском происхождении рудообразующих флюидов на рудопроявлении Арыскан [11-13, 24]. Также на это указывает высокая соленость флюидов и комплексный многокомпонентный состав с хлоридами $\mathrm{Na}$ и К и гидрокарбонатами. Повышенные концентрации В во флюиде и присутствие так называемых «магмафильных» элементов (W, Sb, Mo, Sb) также указывают на участие магматогенного флюида в рудообразовании [25, 26].

Для золоторудных месторождений России (Березовское, Кочкарское) вовлечение в рудообразование флюидов магматического, метаморфического или метеорного происхождения при доминирующей роли магматического флюида является типичным [27]. Для рудопроявления Арыскан зафиксирован широкий интервал солености флюидов от 32 до 3 мас. \% NaClэкв., что может быть интерпретировано как разбавление магматического флюида с повышенной соленостью нагретыми метеорными водами [28].

Подобный разброс солености флюида может также указывать на то, что рудоотложение обеспечивалось гетерофазным магматогенным флюидом, состоящим из высокосоленого раствора и более низкоплотной и низкосоленой флюидной фазы [29]. В пользу этого свидетельствует близкий макро-, микроэлементный и газовый состав флюидных включений с разной соленостью, присутствие включений, гомогенизирующихся в газовую и жидкую фазу в одинаковом интервале температур. Плотности флюидов, рассчитанные с помощью программы Flincor [30] и диаграммы из [28], составили

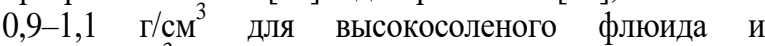
$0,7-0,9$ г $/ \mathrm{cm}^{3}$ для слабосоленой фазы.

\section{СПИСОК ЛИТЕРАТУРЫ}

1. Зайкова Е.В., Зайков В.В. О золотом оруденении в Западной Туве, связанном с девонским магматизмом // Материалы по геологии Тувинской АССР. - Кызыл: Тувинское книжное издво, 1969. - С. 72-76.

2. Кужугет Р.В., Зайков В.В., Анкушева Н.Н. Минералогогеохимические особенности Арысканского рудопроявления золота кварцево-жильного типа в березитах (Западная Тува) // Геология и минерально-сырьевые ресурсы Сибири. - 2017. № 1 (29). - C. 98-110.

3. Рудные формации Тувы / В.В. Зайков, В.И. Лебедев, В.Г. Тюлькин, В.Н. Гречищева, К.С. Кужугет. - Новосибирск: Наука, 1981. - 201 с.

4. Золотое оруденение в зоне Хемчикско-Куртушибинского глубинного разлома (Тува) / Б.Д. Васильев, В.П. Дружков, А.И. Красиков, Г.Ю. Боярко // Рудные формации и месторождения Сибири. - Томск: Изд-во Томского политехнического университета, 1979. - С. 91-95.

5. Безруков О.А. Результаты поисково-оценочных работ в бассейне рек Ак-Суг, Алаш, Хемчик. - Кызыл: Изд-во Тувинской геологоразведочной экспедиции, 1969. - 199 с

6. Борисенко А.С. Анализ солевого состава растворов газовожидких включений в минералах методом криометрии // Использование методов термобарогеохимии при поисках и изучении рудных месторождений / под ред. Н.П. Лаверова. - М.: Недра, 1982. - C. 37-46.

7. Bodnar R.J., Vityk M.O. Interpretation of microthermometric data for $\mathrm{H} 2 \mathrm{O}-\mathrm{NaCl}$ fluid inclusions // Fluid Inclusions in Minerals, Methods and Applications / Eds. B. De Vivo, M.L. Frezzotti. Blacksburg: Virginia Polytechnic Institute \& State University publ., 1994. - P. 117-130.

8. Реддер Э. Флюидные включения в минералах. - М.: Мир, 1978. - T. 1. $-360 \mathrm{c}$

9. Коваленкер В.А., Наумов В.Б., Прокофьев В.Ю. Гетерогенизация флюидов как один из факторов отложения продуктив-

\section{Заключение}

Таким образом, золотое оруденение на рудопроявлении Арыскан сопряжено с процессами березитизации интрузивных и осадочных пород. По минералогогеохимическим особенностям руд рудопроявление можно отнести к малосульфидной золото-кварцевой вулканогенно-плутоногенной формации.

По данным изучения флюидных включений в кварце золотосодержащих жил и березитов рудопроявления Арыскан установлено, что они образовались из магматического гетерофазного углекислотноводного флюида в близких диапазонах температур и давлений. Минералообразование протекало в условиях эволюции (остывания) от $340-320^{\circ} \mathrm{C}$ (березиты) до $145^{\circ} \mathrm{C}$ (поздние золото-теллуридные жилы), при вариациях $f \mathrm{O}_{2}, f \mathrm{~S}_{2}, f \mathrm{Se}_{2}$ и $f \mathrm{Te}_{2}$. Содержания рудных элементов (Cu, $\mathrm{Zn}, \mathrm{As}, \mathrm{Sb}$ и др.) во флюиде отражают состав золотосодержащих минеральных ассоциаций.

Полученные результаты могут иметь практическое значение для региональных прогнознометаллогенических построений, поисков и оценки месторождений и рудопроявлений золота.

Авторы благодарны Е.К. Дружковой и Б.Д. Васильеву за помощь в проведении исследований. Минералого-геохимические и изотопные исследования выполнены по государственному заданию ТувИКОПР СО РАН (0384-2016-0012), термобарогеохимические исследования включений выполнены по государственным заданиям ИГМ СО РАН (0330-2016-0002) и ИМин ЮУ ФНЦ МиГ УрО РАН (2019-2021 г2.).

ных ассоциаций при формировании золоторудных и золотосеребряных месторождений // Минералообразование из вскипающих растворов. - Пермь: Изд-во Пермского университета, 1988. - C. 217-218.

10. Кряжев С.Г., Прокофьев В.Ю., Васюта Ю.В. Использование метода ICP MS при анализе рудообразующих флюидов // Вестник МГУ. Серия 4. Геология. - 2006. - № 4. -С. 30-36.

11. Ohmoto H., Rye R.O. Isotopes of sulfur and carbon // Geochemistry of hydrothermal ore deposits. - N.Y.: John Wiley and Sons, 1979. - P. 509-567.

12. Ohmoto H. Stable isotope geochemistry of ore deposits // Review Mineralogy. - 1986. - V. 16. - P. 491-560.

13. Hoefs J. Stable Isotope Geochemistry. - Berlin; Heidelberg: Springer-Verlag, 2009. - $281 \mathrm{p}$

14. Li Y., Liu J. Calculation of sulfur isotope fractionation in sulfides // Geochimica Cosmochimica Acta. - 2006. - V. 70. - P. 1789-1795.

15. Артемьев Д.С. Рудоносность гидротермально-метасоматических образований Майского рудного поля (Чукотский Автономный Округ): автореф. дис. ... канд. геол.-минерал. наук. - СПб., 2018. $-20 \mathrm{c}$.

16. Петрохимическая характеристика магматических горных пород и гидротермально-метасоматических образований Кедровского золоторудного поля / Г.Г. Попов, Б.Г. Попов, Х.Х. Муратшин, Д.Г. Мизиряк // Разведка и охрана недр. 2017. - № 9. - C. 27-32.

17. Listvenite-related gold deposits of the South Urals (Russia): a review / E.V. Belogub, I.Yu. Melekestseva, K.A. Novoselov, M.V. Zabotina, G.A. Tret'yakov, V.V. Zaykov, A.M. Yuminov // Ore Geology Reviews. - 2017. - V. 85. - P. 247-270.

18. Условия образования Ганеевского золоторудного месторождения, Учалинский рудный район: минералогическая термометрия и изучение флюидных включений / М.В. Заботина, Н.Н. Анкушева, С.Н. Шанина, В.А. Котляров // Минералогия. - 2018. - № 4. - С. 55-67. 
19. Геологическое строение и минералогия Мечниковского месторождения золота, Южный Урал / И.Ю. Мелекесцева, В.В. Зайков, Г.А. Третьяков, К.А. Филиппова, В.А. Котляров // Литосфера. - 2019. - Т. 19. - № 1. - С. 111-138.

20. Спиридонов Э.М. Обзор минералогии золота в ведущих типах $\mathrm{Au}$ минерализации // Золото Кольского полуострова и сопредельных регионов: Труды Всероссийской (с международным участием) научной конференции, посвящённой 80-летию Кольского НЦ РАН. - Апатиты, 26-29 сентября 2010. - Апатиты: Изд-во К\&M, 2010. - С. 143-171.

21. Парагенезисы теллуридов золота и серебра в золоторудном месторождении Флоренсия (Республика Куба) / Н.С. Бортников, Х.Л. Крамер, А.Д. Генкин, Л.Я. Крапива, М. Санта-Крус // Геология рудных месторождений. - 1988. - № 2. - С. 49-61.

22. Barton P.B., Skinner B.J. Sulfide mineral stabilities // Geochemistry of Hydrothermal Ore Deposits / Ed. by H.L. Barnes. New York: John Willey and Sons, 1979. - P. 278-403.

23. Afifi A.M., Kelly W.C., Essene E.J. Phase relations among tellurides, sulfides, and oxides: I. Thermochemical data and calculated equilibria // Economic Geology. - 1988. - V. 83. P. 377-394.

24. Kerrich R. Source processes for Archean Au-Ag vein deposits evidence from lithophile-element systematics of the HollingerMcInture and Buffalo ankerite deposits, Timmins // Canadian Journal of Earth Sciences. - 1989. - V. 26. - P. 755-781.
25. Бор и борные кислоты в эндогенных рудообразующих флюидах / В.Ю. Прокофьев, И.С. Перетяжко, С.3. Смирнов, Б.Р. Тагиров, Е.О. Грознова, Е.А. Самсонова. - М.: Пасьва, 2003. $192 \mathrm{c}$.

26. Trace element and REE geochemistry of the Zhewang gold deposit, southeastern Guizhou Province / L. Kun, Y. Ruidong, C. Wenyong, L. Rui, T. Ping // Chinese Journal of Geochemistry. - 2014. V. 33. - P. 109-118.

27. Бортников Н.С. Геохимия и происхождение рудообразующих флюидов в гидротермально-магматических системах в тектонически активных зонах // Геология рудных месторождений. 2006. - T. 48. - № 1. - C. 3-28.

28. Wilkinson J.J. Fluid inclusions in hydrothermal ore deposits // Lithos. - 2001. - V. 55. - P. 229-272.

29. Состав магматогенных флюидов, факторы их геохимической специализации и металлоносности / А.С. Борисенко, А.А. Боровиков, Л.М. Житова, Г.Г. Павлова // Геология и геофизика 2006. - T. 47. - № 12. - C. 1308-1325.

30. Brown P.E. FLINCOR: a microcomputer program for the reduction and investigation of fluid inclusion data // American Mineralogist. - 1989. - V. 74. - P. 1390-1393.

Поступила 16.06.2020 2.

\section{Информация об авторах}

Kyж⿻zет P.B., кандидат геолого-минералогических наук, ведущий научный сотрудник лаборатории геодинамики, магматизма и рудообразования Тувинского института комплексного освоения природных ресурсов СО PAH.

Анкушева Н.Н., кандидат геолого-минералогических наук, научный сотрудник лаборатории минералогии рудогенеза Института минералогии ЮУ ФНЦ МиГ УрО РАН; старший преподаватель Геологического факультета Южно-Уральского государственного университета.

$\boldsymbol{P e д u н а ~} \boldsymbol{A} . \boldsymbol{A}$., младший научный сотрудник лаборатории рудоносности щелочного магматизма Института геологии и минералогии им. В.С. Соболева СО РАН.

Прокопьев И.Р., кандидат геолого-минералогических наук, научный сотрудник лаборатории рудоносности щелочного магматизма Института геологии и минералогии им. В.С. Соболева СО РАН; старший преподаватель Геолого-геофизического факультета Новосибирского государственного университета.

Ондар Э.-Д.В., преподаватель кафедры горного дела Тувинского государственного университета. 
UDC 553.2: $549.283(571.52)$

\section{ARYSKAN GOLD-SULPHIDE-QUARTZ ORE OCCURRENCE (WESTERN TUVA): CONDITIONS OF FORMATION AND GEOCHEMICAL PECULIARITIES OF FLUIDS}

Renat V. Kuzhuget 1 , rkuzhuget@mail.ru

Natalia N. Ankusheva ${ }^{2,3}$, ankusheva@mail.ru

Anna A. Redina ${ }^{4}$, anna-red@outlook.com

llya R. Prokopyev 4,5 , prokopev_ilya@mail.ru

Ertine Dash V. Ondar 6 , ondar21@mail.ru

1 Tuvinian Institute for Exploration of Natural Resources SB RAS,

117 a, Internatsionalnaya street, Kyzyl, 667007, Russia.

2 Institute of Mineralogy SU FRC MG UB RAS,

1, Ilmensky Reserve, Miass, 456317, Russia.

${ }^{3}$ South Urals State University, Miass,

10, 8 lyulya street, Miass, 456316, Russia.

4 V.S. Sobolev Institute of Geology and Mineralogy SB RAS,

3, Academician Koptyug avenue, Novosibirsk, 630090, Russia.

${ }^{5}$ Novosibirsk State University,

1, Pirogov street, Novosibirsk, 630090, Russia.

6 Tuvan State University,

36, Lenin street, Kyzyl, 667000, Russia.

The relevance of the research is defined by the need to determine the genesis and formation conditions of gold deposits from Tuva Republic for improving the efficiency of geological prospecting and increasing the gold mineral resource base of the region.

The aim of the research is to examine the conditions of fluid formation and geochemical peculiarities of Aryskan gold ore occurrence in Western Tuva.

Analytical methods. The temperatures, fluid composition, salinity, and trapping pressures were examined due to fluid inclusion study by means of Linkam TMS-600 cryostage equipped with Olympus BX 51 optical microscope; gas composition of fluid inclusions was detected using Ramanor U-1000 Raman spectrometer equipped with Horiba DU420E-OE-323 detector and Millennia Pro (Spectra-Physics) laser; bulk element composition of fluid was determined on Agilent 6890 gas chromatograph, extracted anion amounts of fluid were detected using TSVET-3000 ion chromatograph, cations and trace elements - by means of ICP MS (Elan-6100); S isotopic compositions were specified on Finnigan MAT Delta gas mass-spectrometer.

Results. We specified that early beresites of Aryskan ore occurrence were formed due to $\mathrm{CO}_{2}$ water-chloride fluid with salinity ranged between 4,9 and 41,5 wt. \% NaCl equiv. and temperatures from 250 to $340{ }^{\circ} \mathrm{C}$. The Au-bearing mineral associations were formed at $\mathrm{P} \sim 1,8 \mathrm{kbar}$ ( $\sim 5,4 \mathrm{~km}$ depth) in mesoabissal environment due to $\mathrm{CO}_{2}$ watered fluids contained $\mathrm{NaCl}-\mathrm{KCl}-\mathrm{H}_{2} \mathrm{O}, \mathrm{NaCl}-\mathrm{Na}_{2} \mathrm{HCO}_{4}-\mathrm{H}_{2} \mathrm{O}$ and $\mathrm{NaCl}-\mathrm{H}_{2} \mathrm{O}$ with salinity from 2,9 up to $32,9 \mathrm{wt}$. \% NaCl equiv. in front of the temperatures ranged between $290-145{ }^{\circ} \mathrm{C}$ (I Au-bearing substage $-290-145^{\circ} \mathrm{C}$, II Au-bearing substage $-270-160^{\circ} \mathrm{C}$ ) with varying $\mathrm{fO}_{2}, \mathrm{fS}_{2}, f \mathrm{Se}_{2}$ and $\mathrm{Te} \mathrm{T}_{2}$. The isotopic $\delta^{34} \mathrm{~S}_{\mathrm{H}_{2} \mathrm{~S}}$ (from $-0,5$ up to $+1,1 \%$ ) and salt composition of fluids and trace elements indicate the magmatic genesis.

Key words:

Gold, beresites, gold deposits, quartz, Tuva, fluid inclusions, trace elements, sulphur isotopic composition.

We thank E.K. Druzhkova and B.D. Vasiliev for help in conducting research. Mineralogical, geochemical and isotopic researches are supported by the State Contract of TuvIENR SB RAS (0384-2016-0012), fluid inclusion study was supported by State Contracts of the Institute of Geology and Mineralogy SB RAS (0330-2016-0002) and Institute of Mineralogy SU FRC MiG UB RAS (project for 2019-2021).

\section{REFERENCES}

1. Zaykova E.V., Zaykov V.V. O zolotom orudenenii v Zapadnoy Tuve, svyazannom s devonskim magmatizmom [Gold mineraliza- tion in the Western Tuva related to Devonian magmatism]. Materialy po geologii Tuvinskoy ASSR [Materials in geology of Tuva ASSR]. Kyzyl, TGRE Publ., 1969. pp. 72-76. 
2. Kuzhuget R.V., Zaykov V. V., Ankusheva N.N. Mineral and geochemical features of the Aryskanskoye gold-quartz mineralisation in beresites (Western Tuva). Geology and mineral resources of Siberia, 2017, no. 1 (29), pp. 98-110. In Rus.

3. Zaykov V.V., Lebedev V.I., Tulkin V.G., Grechischeva V.N., Kuzhuget K.S. Rudnye formatsii Tuvy [Ore formations of Tuva]. Novosibirsk, Nauka Publ., 1981. 201 p.

4. Vasiliev B.D., Druzhkov V.P., Krasikov A.I., Boyarko G.Yu. Zolotoe orudenenie $\mathrm{v}$ zone Khemchiksko-Kurtushibinskogo glubinnogo razloma (Tuva) [Gold mineralization in KhemchikKurtushibinsky fault, Tuva]. Rudnye formatsii $i$ mestorozhdeniya Sibiri [Ore formations and deposits of Siberia]. Tomsk, TPU Publ., 1979. pp. 91-95.

5. Bezrukov O.A. Rezultaty poiskovo-otsenochnykh rabot v basseyne rek Ak-Sug, Alash, Khemchik [Results of prospecting of basin of Ak-Sug, Alash and Khemchik rivers]. Kyzyl, TGRE Publ., 1969. $199 \mathrm{p}$.

6. Borisenko A.S. Analiz solevogo sostava rastvorov gazovozhidkikh vklyucheniy v mineralakh metodom kriometrii [Analysis of salt composition of solutions of gas-liquid inclusions in minerals using the cryometry method]. Ispolzovanie metodov termobaroge okhimii pri poiskakh i izuchenii rudnykh mestorozhdeniy [Use of thermobarogeochemistry methods for prospecting and studying ore deposits]. Ed. by N. Laverov. Moscow, Nauka Publ., 1982. pp. 37-46.

7. Bodnar R.J., Vityk M.O. Interpretation of microthermometric data for $\mathrm{H}_{2} \mathrm{O}-\mathrm{NaCl}$ fluid inclusions. Fluid Inclusions in Minerals, Methods and Applications. Eds. B. De Vivo, M.L. Frezzotti. Blacksburg, Virginia Polytechnic Institute \& State University Publ., 1994. pp. 117-130.

8. Roedder E. Flyuidnye vklyucheniya v mineralakh [Fluid inclusions in minerals]. Moscow, Mir Publ., 1987. 360 p.

9. Kovalenker V.A., Naumov V.B., Prokofiev V.Yu. Geterogenizatsiya flyuidov kak odin iz faktorov otlozheniya produktivnykh assotsiatsy pri formirovanii zolotorudnykh i zoloto-serebryanykh mestorozhdeniy [Heterogenization of fluids as one of the factors of the deposition of productive associations during the formation of gold and gold-silver deposits]. Mineraloobpazovanie iz vskipayushchikh rastvorov [Mineralogy from incubating solutions]. Perm, Perm University Publ., 1988. pp. 217-218.

10. Kryazhev S.G., Prokofiev V.Yu., Vasyuta Yu.V. Ispolzovanie metoda ICP MS pri analize rudoobrazuyushchikh flyuidov [The usage of ICP MS for ore-forming fluid analysis]. Vestnik $M G U$, 2006, no. 4, pp. 30-36.

11. Ohmoto H., Rye R.O. Isotopes of sulfur and carbon. Geochemistry of hydrothermal ore deposits. N.Y., John Wiley and Sons, 1979. pp. 509-567.

12. Ohmoto H. Stable isotope geochemistry of ore deposits. Review Mineralogy, 1986, vol. 16, pp. 491-560.

13. Hoefs J. Stable Isotope Geochemistry. Berlin, Heidelberg, Springer-Verlag, 2009. $281 \mathrm{p}$.

14. Li Y., Liu J. Calculation of sulfur isotope fractionation in sulfides. Geochimica Cosmochimica Acta, 2006, vol. 70, pp. 1789-1795.

15. Artemiev D.S. Rudonosnost gidrotermalno-metasomaticheskikh obrazovaniy Mayskogo rudnogo polya (Chukotskiy Avtonomny Okrug). Avtoreferat Kand. nauk. [Ore content of hydrothermal and metasomatic formations of the May ore field (Chukotka Autonomous Okrug). Cand. Diss. Abstract]. Petersburg, 2018. 20 p.

16. Popov G.G., Popov B.G., Muratshin H.H., Miziryak D.G. Petrochemical characteristic of magmatic rocks and gidrotermalmetasomatic of formations of kedrovsky of the gold field. Pro- spect and protection of mineral resources, 2017, no. 9, pp. 27-32. In Rus.

17. Belogub E.V., Melekestseva I.Yu., Novoselov K.A., Zabotina M.V., Tret'yakov G.A., Zaykov V.V., Yuminov A.M. Listvenite-related gold deposits of the South Urals (Russia): a review. Ore Geology Reviews, 2017, vol. 85, pp. 247-270.

18. Zabotina M.V., Ankusheva N.N., Shanina S.N., Kotlyarov V.A. Formation conditions of the Ganeevskoe gold deposit, Uchaly ore district: mineralogical thermometry and fluid inclusion study. Mineralogy, 2018, no. 4, pp. 55-67. In Rus.

19. Melekestseva I.Yu., Zaykov V.V., Tret'yakov G.A., Filippova K.A., Kotlyarov V.A. Geological structure and mineralogy of the Mechnikovskoe gold deposit, the Southern Urals. Litosfera, 2019, vol. 19, no. 1, pp. 111-138. In Rus.

20. Spiridonov E.M. Obzor mineralogii zolota v vedushchikh tipakh Au mineralizatsii [Review of gold mineralogy in major types of $\mathrm{Au}$ mineralization]. Zoloto Kolskogo poluostrova $i$ sopredelnykh regionov. Trudy Vserossiiskoy (s mezhdunarodnym uchastiem) nauchnoy konferentsii, posvyashchennoy 80-letiyu Kolskogo NC RAN [Gold of the Kola Peninsula and Adjacent Regions. Proceedings of the Russian (with International Participants) Conference Dedicated to the $80^{\text {th }}$ Anniversary of the Kola Scientific Center (Russian Academy of Sciences)]. Apatity, K\&M Publ., 2010. pp. 143-171.

21. Bortnikov N.S., Kramer Kh., Genkin A.D., Krapiva L.Ya., Santa Cruz M. Paragenesis of Gold and Silver Tellurides in the Florencia Gold Deposit, the Republic of Cuba. International Geology Review, 1988, vol. 30 (3), pp. 294-306.

22. Barton P.B., Skinner B.J. Sulfide mineral stabilities. Geochemistry of Hydrothermal Ore Deposits. Ed. by H.L. Barnes. New York, John Willey and Sons, 1979. pp. 278-403.

23. Afifi A.M., Kelly W.C., Essene E.J. Phase relations among tellurides, sulfides, and oxides: I. Thermochemical data and calculated equilibria; II. Applications to telluride-bearing ore deposits. Economic Geology, 1988, vol. 83, pp. 377-394.

24. Kerrich R. Source processes for Archean Au-Ag vein deposits: evidence from lithophile-element systematics of the HollingerMcInture and Buffalo ankerite deposits, Timmins. Canadian Journal of Earth Sciences, 1989, vol. 26, pp. 755-781.

25. Prokofev V.Yu., Peretyazhko I.S., Smirnov S.Z., Tagirov B.R., Groznova E.O., Samsonova E.A. Bor i bornye kisloty v endogennykh rudoobrazuyushchikh flyuidakh [Boron and boric acid in endogenous ore-forming processes]. Moscow, Pasva Publ., 2003. $192 \mathrm{c}$.

26. Kun L., Ruidong Y., Wenyong C., Rui L., Ping T. Trace element and REE geochemistry of the Zhewang gold deposit, southeastern Guizhou Province. Chinese Journal of Geochemistry, 2014, vol. 33, pp. 109-118.

27. Bortnikov N.S. Geochemistry and origin of the ore-forming fluids in hydrothermal-magmatic systems in tectonically active zones. Geology of Ore Deposits, 2006, vol. 48, no. 1, pp. 3-28.

28. Wilkinson J.J. Fluid inclusions in hydrothermal ore deposits. $\mathrm{Li}$ thos, 2001, vol. 55, pp. 229-272.

29. Borisenko A.S., Borovikov A.A., Zhitova L.M., Pavlova G.G. Composition of magmatogene fluids and factors determining their geochemistry and metal contents. Russian Geology and Geophysics, 2006, vol. 47, no. 12, pp. 1308-1325.

30. Brown, P.E. FLINCOR: a microcomputer program for the reduction and investigation of fluid inclusion data. American Mineralogist, 1989, vol. 74, pp. 1390-1393.

Received: 16 June 2020.

Information about the authors

Renat V. Kuzhuget, Cand. Sc., lead researcher, Tuvinian Institute for Exploration of Natural Resources SB RAS.

Natalia N. Ankusheva, Cand. Sc., scientist, Institute of Mineralogy SU FRC MG UB RAS; senior lecturer, South Urals State University.

Anna A. Redina, junior researcher, V.S. Sobolev Institute of Geology and Mineralogy SB RAS.

Ilya R. Prokopyev, Cand. Sc., scientist, V.S. Sobolev Institute of Geology and Mineralogy SB RAS; senior lecturer, Novosibirsk State University.

Ertine Dash V. Ondar, teacher, Tuvan State University. 